NBER WORKING PAPER SERIES

\title{
KEEPING COLLEGE OPTIONS OPEN: \\ A FIELD EXPERIMENT TO HELP ALL HIGH SCHOOL SENIORS THROUGH THE COLLEGE APPLICATION PROCESS
}

\author{
Philip Oreopoulos \\ Reuben Ford \\ Working Paper 22320 \\ http://www.nber.org/papers/w22320 \\ NATIONAL BUREAU OF ECONOMIC RESEARCH \\ 1050 Massachusetts Avenue \\ Cambridge, MA 02138 \\ June 2016
}

This project would not have been possible without the support and enthusiasm of many people. The Ministry of Training, Colleges, and Universities (MTCU), partnered with the Ministry of Education and the Social Research and Demonstration Corporation (SRDC) to fund and implement the experiment. We are especially grateful to Noah Morris, Jean-Pierre Voyer, Sam Andrey, Chris Ste-Croix, Travis Coulter, Galina Buryak, Jennifer Da Silva, Lisa Stanley, Noemi Varga and Doug Calderwood-Smith from MTCU for championing the research. SRDC staff members Dominique Leonard, Sheila Currie, Heather Smith Fowler, Claudia Nicholson, Danielle Patry, Isaac Kwakye, Natalie Conte, Bart Millson, Taylor Shek-wai Hui provided expert field operational and data analytical experience. We are grateful to both Tony Tullio and Inorbital as well as Honrio Cham and Radii for helping develop the program's website in different phases, Laurie Labelle for designing the program's brochures and other materials, Ryan Dunn and Jason Rogers for developing the financial aid calculator, Matt Boire and Sabina Dobrer for developing the 'Where Would You Go' tool and Boaz Beeri for producing its videos. We also greatly benefited from the facilitators who delivered the program and Shayne Hillier who provided IT field support. And we are indebted to all the principals, counselors, teachers, and students who participated in the program as well as the staff at OSAP, OUAC and OCAS who supported the application processes. Comments and feedback from several seminars and conferences were also greatly appreciated. Any errors or omissions are the sole responsibility of the authors. The views expressed herein are those of the authors and do not necessarily reflect the views of the National Bureau of Economic Research.

NBER working papers are circulated for discussion and comment purposes. They have not been peer-reviewed or been subject to the review by the NBER Board of Directors that accompanies official NBER publications.

(C) 2016 by Philip Oreopoulos and Reuben Ford. All rights reserved. Short sections of text, not to exceed two paragraphs, may be quoted without explicit permission provided that full credit, including (O) notice, is given to the source. 
Keeping College Options Open: A Field Experiment to Help All High School Seniors Through the College Application Process

Philip Oreopoulos and Reuben Ford

NBER Working Paper No. 22320

June 2016

JEL No. I20,I23,I28,J20

\begin{abstract}
Recent research suggests that the college application process itself prevents access. This paper reports results from a large school-based experiment in which application assistance is incorporated into the high school curriculum for all graduating seniors at low-transition schools. Over three workshops, students were guided to pick programs of interest that they were eligible for, apply for real, and complete the financial aid application. The goal was to create a college option for exiting students to make the transition easier and more salient. On average, the program increased application rates from 64 to 78 per cent. College enrolment increased the following school year by 5.2 percentage points with virtually all of this increase in two-year community college programs. The greatest impact was for students who were not taking any university-track courses in high school: the application rate for these students increased by 24 percentage points with a nine per cent increase in two-year college enrolment. A second experiment was conducted two years later to explore several variations of the program. Offering personal assistance without waiving application fees had a negligible or even negative impact on applications and enrollment. Using laptops in homeroom classrooms instead of sending students to computer labs while combining the initial 2 workshops into one full-morning session increased application rates. However, subsequent enrollment effects were negligible. We provide some evidence consistent with the possibility that decreased guidance in choosing eligible programs was responsible for the second-experiment's decline in enrollment impacts.
\end{abstract}

\author{
Philip Oreopoulos \\ Department of Economics \\ University of Toronto \\ 150 St. George Street \\ Toronto, ON M5S 3G7 \\ CANADA \\ and NBER \\ philip.oreopoulos@utoronto.ca
}

Reuben Ford

Social Research and Demonstration Corporation

789 West Pender Street

Suite 440

Vancouver, British Columbia, V6C 1H2

rford@srdc.org 


\section{Introduction}

In most school systems, the transition from Grade 7 to 8 is straightforward. Students who complete Grade 7 are automatically enrolled in Grade 8 and can show up the following September at the same school, confident that there will be a spot waiting for them. Even for the transition from Grade 8 to 9, when students switch from elementary to high school, resources are provided to make the adjustment simple. Since all students experience this transition, much of the process has become automatic, and school staff guide students (often in class) and parents through any remaining non-automatic choices, such as choosing courses or choosing schools outside default catchment areas. Administrators help ensure everyone gets to the right place the following year.

The same cannot be said for moving from Grade 12 to college. Students who plan to attend college must complete prerequisite courses in high school with sufficient grades to qualify for acceptance into a program. But sufficient grades do not guarantee a spot: even qualified students still must choose which programs and colleges to apply, complete each application and pay application fees, and often must take standardized readiness assessment tests (like the ACT or SAT) and write entrance essays. Those in financial need must complete an application for federal assistance and may benefit from applying elsewhere for scholarships, awards, and additional financing. Finally, at the end of the transition period, students must receive and accept an offer, receive and manage financial aid, register and pay fees, choose courses, and upend their daily routine to begin classes at their new school.

Historically, the majority of students ended their education with high school. College was left to a small elite, and if an exceptional student wanted to go to college, she was left to 
figure things out on her own. But times have changed. Most developed countries have seen a steady rise in the number of youth with college intentions: for example, by 2015, 70 percent of recent high school graduates in the United States were enrolled in postsecondary education. ${ }^{1}$ Despite this trend, the transition process from high school to college has largely remained unchanged. Support varies greatly by school and region, with less support often in poorer neighborhoods. ${ }^{2}$

Transition barriers to college and other programs are usually ignored in economics and public policy. For decisions such as college attendance involving large, long-term costs and benefits, the marginal costs of taking action and applying are often perceived as "too small to matter.” However, research in behavioral economics, psychology, and neuroscience provides clear evidence to the contrary. ${ }^{3}$ It is in our nature to sometimes focus too much on the present, or stick too much to routine. ${ }^{4}$ Actions that require taking time out of our routine, that are complex and without social support, and whose benefits are very long-term and uncertain are tempting to put off. Stress -- for example, from lack of time or money -- exacerbates these leanings. ${ }^{5}$

The FAFSA (Free Application for Federal Student Aid) provides a prototypical example of how seemingly small differences in take-up procedures can lead to differences in participation. ${ }^{6}$ The form contains more than 100 questions, including ones about parents' exact

\footnotetext{
${ }^{1}$ Bureau of Labor Statistics, Economic News Release, April 28, 2016.

${ }^{2}$ See, for example, New York Times article, "Guiding a First Generation to College," April 26, 2016, by Tina Rosenberg.

${ }^{3}$ See, for example, Stanovich et al., 2012, and Frederick et al., 2002,

${ }^{4}$ See McClure et al., 2004; Kable and Glimcher, 2007; Kable and Glimcher, 2010, Stanovich et al., 2012.

${ }^{5}$ Lavecchia, Liu, and Oreopoulos (2016) provide a more detailed theoretical and empirical overview of behavioral economics in the education context.

${ }^{6}$ The need to save for retirement is commonly mentioned as another example. Standard models assume that individuals are forward looking, able to forecast how much they will need to save (or that they have access to services that help them do this), and face little difficulty following through with their plans. Simply changing the default action (from having to opt-into pension plans to being automatically enrolled), or requiring individuals to
} 
income, social security numbers, highest level of education, students' savings, working income and other untaxed income. Anyone needing college aid must complete this form. Researchers and government officials have speculated that some fail to apply and to go to college because they are either unaware of the FAFSA, or cannot overcome its complexity or inconvenience. ${ }^{7}$

To test this theory, Bettinger et al. (2012) partnered with H\&R Block, a large tax preparation company that helps millions of low-income households file tax forms each year in the United States. Much of the information needed to complete the FAFSA -- including the most difficult to collect -- is the same information collected during a visit at H\&R Block. Parents whose income likely qualified their Grade 12 children for college aid were randomly selected into the FAFSA assistance group. They were invited to continue to work with a tax professional for an extra 10 minutes to receive help with the FAFSA for their child. ${ }^{8}$ Complete or nearcomplete FAFSAs were then sent home with a pre-paid envelope and instructions for the child to sign and mail the form to the Department of Education. Parents selected into the control group were given only a booklet about college, and parents selected into the information group were given an outline of tuition costs at local public colleges along with the likely grant and loan aid available if a FAFSA was filed, but were not given filing assistance. Grade 12 students whose parents were assigned to the information group were no more likely to file a FAFSA or attend college the following school year than the control group. Those assigned to the FAFSA assistance group, however, were 16 percentage points more likely to file and 8 percentage points

make an active decisions regarding their contributions, or just simplifying the application process increases savings significantly (Beshears et al., 2013; Carroll et al., 2009; Chetty et al., 2014).

7 The 2005 Congressional Advisory Committee on Student Financial Assistance concluded that "millions of students and adult learners who aspire to college are overwhelmed by the complexity of student aid. Uncertainty and confusion rob them of its significant benefits. Rather than promote access, student aid often creates a series of barriers - a gauntlet that the poorest students must run to get to college".

${ }^{8}$ The FAFSA study also examined impacts from offering application assistance to young adults out of school with no more than a high school education. The assistance increased college enrollment by about 2 percentage points. 
more likely to attend. They were also just as likely to attend for two years, which is notable given that the FAFSA assistance was only provided during the transition year.

Offering personal assistance to complete the FAFSA in this way can affect college enrollment through several channels. The assistance increases visibility of the form and makes parents more aware of financial aid possibilities. It reduces complexity by avoiding the need to review detailed instructions and uncertainty around whether the form is filled out correctly. Offering support while already at an office minimizes disruption and lowers the opportunity cost of time. It generates reassurance and encouragement from having a professional promote the form. The assistance also makes the FAFSA more salient, reminding parents of the time-sensitive benefits of filling it out.

The program examined in the FAFSA study, however, only helped with one component of the transition to college - applying for financial aid. Applicants still had to determine which colleges and programs to apply to. They still had to pay program application fees, register for courses, and complete the SAT or ACT. And only children of parents visiting H\&R Block who agreed to receive $\$ 20$ to participate in a study vaguely about college were affected.

This paper presents results of an experiment motivated by the FAFSA study to explore a more scalable program called LifeAfterHighSchool, which offered personal assistance for both financial aid and program applications, and provided this support directly to students at lowtransition high schools (where fewer than half of graduating seniors enter college the following school year). The first pilot of the experiment was conducted in 2011-12 across the Canadian province of Ontario, where there are typically no additional essay or standardized test requirements for postsecondary applications. Principals agreed to give up 3 classes over the school year for the program. During the first class, Grade 12 students were guided through 
browsing local college programs for which they would likely be accepted into, and were asked to choose up to 5 for which they would like to keep the option to attend open. They also walked through a simple financial aid and budget calculator to determine how they could afford to go to college. In the second class (about three weeks later), students were guided through completing their applications on the actual central application website, with LifeAfterHighSchool waiving the regular application fees. In the final class, students were guided to begin an application for government student aid. Parents were mailed and emailed instructions on how to complete the remainder of the form.

LifeAfterHighSchool increased the college application rate for graduating seniors from 64 to 78 percent, with most of this increase coming from 2-year college applications. College enrollment correspondingly increased the following school year by 5.2 percentage points, and virtually all of this increase was due to additional enrollment at 2-year colleges. The program had similar effects for males and females, and for rural and urban schools. Its largest effects were on graduating students who were not taking any university-track courses. The application rate for these students increased by 24 percentage points. The 2-year college enrollment rate for them increased by 9 percentage points..

A second LifeAfterHighSchool experiment was conducted two years later to explore variations on the first program setup. Offering personal assistance without waiving application fees had a negligible or even negative impact on applications and enrollment. Offering fee waivers and providing only instructions to school staff for how to implement the program led to similar increases in applications and enrollment as in the first program. Using laptops in homeroom classrooms instead of sending students to computer labs, while simultaneously combining the initial 2 classes into one full-morning session, increased application rates. 
However, subsequent enrollment effects were negligible. We provide some evidence consistent with the possibility that decreased guidance in choosing eligible programs was responsible for the decline in enrollment impact. Better guidance in picking appropriate programs and waiving application fees are clearly important conditions for providing college transition support directly to low-transition high schools.

The next section provides more details of the LifeAfterHighSchool program design. In section III, we discuss actual program fidelity to the original design. Section IV describes our data and randomized difference in differences methodology. Sections V and VI present results from the experiment's first and second pilots respectively. We discuss results in Section VII, placing them in context with other recent studies and discussing their implications for scaling up given relatively low implementation costs.

\section{Program Design}

The underlying goal of the LifeAfterHighSchool program was to help, during class time, virtually all graduating seniors at low transition schools through the college application process so that they left school in June with an offer of acceptance from a program they helped choose, and with guaranteed financial aid. The premise was that the program would make crossing the bridge from high school to college an easier path to take. The program was deliberately inclusive: all students at participating schools with at least 4 years of high school education (call them Grade 12 students) were eligible to receive the program's application assistance. We adopted this inclusive approach to make the program easier for schools to implement; rather than 
having to target individual students on the basis of their likelihood of graduating, whole classes could be scheduled together. The use of class time as well as the covering of application fees minimized students' opportunity cost. We also targeted all students regardless of their postsecondary intentions to avoid stigmatizing students who were not on track to continue on to college, but also to expose students at the margin to possible positive peer effects. We tried to communicate the message that whether a student was sure she wanted to go to college or not, she could not keep open the option to go without applying now. Hence, the slogan of the LifeAfterHighSchool program was 'Keep Your Options Open'.

\section{School Selection}

The LifeAfterHighSchool pilot was funded and supported by the Ontario Ministry of Training, Colleges, and Universities (MTCU) in partnership with the Ministry of Education. The province of Ontario is a particularly attractive region to consider application assistance because no additional standardized tests or essays are required to be considered for most college and university programs. In theory, students need only identify which programs they wish to be considered for, and agree to have their high school transcripts sent for evaluation. In reality, students are usually invited to attend college information sessions outside class time to learn how to navigate through the program and financial aid applications. Two centralized application services offer websites - one for 2-year community colleges and one for 4-year universities - for applying to virtually all programs in the province, with one fee covering up to 
five applications. ${ }^{9}$ A separate website allows students to create accounts to apply for Ontario student aid.

We targeted schools with the lowest college transition rates in the province, conditional on 1) being commuting distance from a college (within 50km), 2) having at least 100 Grade 12 students recorded in 2007-08 (the latest data we had at the time of recruiting), and 3) not being an adult or alternative education center. 126 schools, generally with under half of Grade 12 students going on to college the following year, were invited to participate for a random chance to be offered LifeAfterHighSchool. Most of the principals responded enthusiastically, although 12 declined to participate for various reasons, including resource or timing concerns, insufficient computer lab space, or feeling that the program was not appropriate for their particular school. Some failed to respond in time to the offer to be in the study. A few additional schools were dropped for budgetary reasons, leaving a total of 86 schools.

Half of these schools were randomized to receive the program, and the other half were assigned to the control group. In cases where there was more than one school within a district, at least one school was assigned to the program, and at least one was assigned to the control group. Table 1 provides descriptive means for the cohort of Grade 12 students at program and control schools in the year prior to the program's implementation, and shows that random assignment successfully balanced mean characteristics between the two groups. The data are from student files from the Ministry of Education, aggregated at the school level (and described in more detail in Section IV). In column one, Grade 12 course grades in 2010-11, weighted by student size, averaged 64.7 percent for control schools, compared to 64.3 percent for program schools. Only about half these students took university-level courses, which are required pre-requisites for

\footnotetext{
${ }^{9}$ In Canada, the term 'college' typically refers to 2-year community colleges while 'university' refers to 4-year colleges. If not specified in the paper, 'college' refers to any postsecondary institution, as the term is used in the United States.
} 
admission into 4-year programs. ${ }^{10}$ Less than half applied to postsecondary programs that year, and 30 percent subsequently enrolled by the following school year.

Note that only 52.4 percent of the entire 2010-11 Grade 12 sample in the control group actually graduated and left high school the following year. The main reason appears to be that many had fewer than 21 credits at the start of the year, making it unlikely they would have attained the 30-credit graduation requirement by the end of the year. Another reason is that some graduates stay for another year to boost their grade average before applying to college. Since we cannot directly help these students apply or get accepted into a program the following year, average treatment effects with them in the sample will be smaller than without. Consequently, we estimate treatment effects for students with at least 21 credits at the start of Grade 12, and for students that left high school the following year (a behavior that we show that is not determined by the treatment). In all sample specifications, background characteristics appear to be well balanced between program and control schools, as is expected with random assignment.

\section{The Workshops}

The LifeAfterHighSchool program included three classes, or 'workshops', each about 60 to 70 minutes in length, in which Grade 12s were directed to computer labs instead of their

\footnotetext{
${ }^{10}$ In Ontario, it is more difficult to enroll in university-level courses in Grade 12 for students who did not follow academic level course progressions throughout high school. Grade 9 students choose whether to take 'applied' or 'academic' level courses, such as in English or Math. Students that successfully complete the Grade 9 academic course may proceed to either the Grade 10 academic or the Grade 10 applied course. Those who successfully complete the Grade 9 applied course may proceed to the Grade 10 applied course, but must successfully complete a transfer course if they wish to proceed to the Grade 10 academic course. The Grade 10 academic and applied courses prepare students for particular destination-related courses in Grade 11. The Grade 11 and 12 mathematics curriculum offers preparation courses for university, college, and the workplace. These courses affect the postsecondary programs students are eligible to apply for. Students cannot apply to university programs without university-level courses. Students taking workplace-type courses still have 2-year community college options, but far fewer than if they had taken college-type courses instead.
} 
regularly scheduled classes. Schools were asked to keep students grouped together with their regular classmates, so that each teacher could redirect their entire class to a computer lab to participate. A key tool used in the workshops was the LifeAfterHighSchool website, which was designed to provide students a 'one-stop-shop' with directed access to application websites, informational videos, tools for identifying suitable programs for each student, and a financial aid and budget calculator.

The class that was most often substituted with LifeAfterHighSchool workshops was English - an obvious choice, being the only mandatory Grade 12 course in Ontario. Unfortunately, not all Grade 12 students were enrolled in English in the first semester, and some had already completed the course. Staff, therefore, tried to schedule workshops as direct substitutes for classes as much as possible, but sometimes invited only a subset of students from a class to attend a workshop. Make-up workshops were added when possible for students who missed earlier ones. Schools were given the choice to have workshops administered by external facilitators (many of whom had teaching degrees) or to deliver the program with internal staff after receiving training. Approximately half of the treated schools chose each option.

\section{Workshop One}

Delivery of the first workshop began in October 2011. Students were first shown a 5 minute video promoting the possible benefits of college, and describing the program. ${ }^{11}$ The video emphasized a variety of fields of study, especially vocational options. Students then created a personal account using an assigned registration card. After verifying their email

\footnotetext{
${ }^{11}$ The introductory video can be located here: https://vimeo.com/30165296 (accessed on May 4, 2016). The material was based, in part, on the information experiment used by Oreopoulos and Dunn (2013), which generated increased educational aspirations, aid expectations, and interest in obtaining further college information.
} 
addresses, students were shown a follow-up video introducing them to the first workshop. On the LifeAfterHighSchool website, they were instructed to click on the link 'Where Would You Go?' and enter previous Grade 11 and expected Grade 12 course marks (transcripts were provided by facilitators in case students could not remember). The website then produced a comprehensive list of 2- and 4-year programs at nearby colleges and universities (within 40km) for which students likely met eligibility requirements. ${ }^{12}$ Each program included a link to its official website, the name of the associated college (and a link to the college's main site), the degree type, program requirements for eligibility, and a list of the most common occupations associated with workers with the same degree. Students could filter or expand their list to show programs by length (2 years or less versus more than 2 years), programs farther than $40 \mathrm{~km}$ away, programs based on their personalized interests, and programs that would (or would not) lead to office-type jobs. They were asked to click on programs of possible interest and indicate their preferred choice and other favorites in a personal folder on the web page and email it to themselves.

A second component of Workshop 1, for students that had time, involved exploring a simple financial aid and budget calculator. After clicking 'How Would You Go?', students were asked five questions that could be answered using a drop-down menus about family status, number of siblings and number already attending college, approximate parents' income, and whether they would live at home or in residence during college. The calculator produced a rough estimate of the students' grant and loan eligibility, and displayed these amounts as part of an overall monthly and annual budget specific to enrolling in the students' preferred program of

\footnotetext{
${ }^{12}$ Many students seemed pleasantly surprised with the variety of options listed. They may have initially associated college mostly with a bachelor's program in Arts. Initially listing only programs for which students would likely be accepted if they applied may have helped reduce anxiety and other challenges surrounding sorting through longer lists. Students could relatively quickly assess which interesting programs would be worth seriously considering.
} 
interest. Students could then modify cost and revenue assumptions to see how their overall budget would be affected, and could then email a copy of the budget to themselves.

\section{Workshop Two}

To allow time for students to browse possible college programs outside of class, Workshop 2 was scheduled several weeks after Workshop 1, in November and December. ${ }^{13}$ All Grade 12 students were again assigned to computer labs instead of attending regularly scheduled classes. They were shown a 5 minute video introducing the actual application process, and were asked to $\log$ on to the LifeAfterHighSchool website and click on either a link to OCAS (the Ontario College Application Service) for applying to 2-year community colleges or to OUAC (the Ontario Universities' Application Centre) for 4-year universities. The website offered guidance and videos to help students through the process. Facilitators were also on hand to answer questions and help out during the workshop. Like the FAFSA, many questions - such as date of birth and address - were straightforward to answer, but other questions - such as students' Ontario Education Number - may have required the assistance of a guidance counselor or facilitator. Uncertainty about how to navigate through sections asking questions about work experience (which usually students need not complete), type of program, expected start dates, or citizenship may have also slowed students down or caused hesitation. With the facilitators' assistance, most students were able to apply to multiple programs during the workshop. Programs could be added, deleted, or changed until the application deadline in January (OUAC) or February (OCAS).

An important part of Workshop Two was the waiving of the application fee. Students could apply for up to five community college or three university programs and bypass the

\footnotetext{
${ }^{13}$ Few students, however, logged into the web site between workshops.
} 
approximately $\$ 100$ fee. This component was expected be especially important to persuade students that they had "nothing to lose" by applying, especially for those who were doubtful about wanting to enroll in post-secondary education. The application fee could act as a significant barrier to disadvantaged students' learning about their actual eligibility and likelihood of acceptance. To administer the fee waiver, students were asked to indicate on their application an option to pay via online banking. Online banking payments were not due immediately. Students could then copy their application number (whether the application was finalized or not) and paste it into the 'Pay for Free' section of the LifeAfterHighSchool webpage, and not have to pay on their own.

\section{Workshop Three}

The third workshop took place shortly after the Ontario Student Aid Program (OSAP) website became available in May. This session focused on guiding students through the financial aid application process. In the same year that the program was implemented, the province introduced a tuition tax credit for any student with household income less than $\$ 150,000$. The application process for the credit and for the financial aid was similar, so virtually all students at program schools could be motivated to attend Workshop 3 to keep their

financial aid options open. Parents were notified in advance through a school letter that during the workshop their Grade 12 child would partially complete the financial aid application form, and that their input would likely be required to enter the remaining information (such as household income).

Students watched a short video about college affordability and the OSAP application. The workshop emphasized at least opening an account to start an application, and completing the 
form as far as possible. Opening an account required entering a students' Social Insurance Number (SIN). Email, snail mail, and morning announcements were used to remind students to bring their SIN. Students that did not were sometimes given the option of sitting in on the session and observing another student, or were told to attend a later workshop with their SIN, or to follow-up directly with a guidance staff once they had obtained it.

\section{Additional Support}

In cases where students did not attend a workshop or were not able to finish an application, school counselors provided rescheduled opportunities or even one-on-one assistance (at the counselors' discretion, and depending on time constraints). Counselors were informed of students who had registered but not yet completed a program application and were encouraged to follow-up, especially with those thought to benefit. Counselors at about half of the program schools reported using active individual follow-up to help students complete applications.

Promotional material was used to advertise LifeAfterHighSchool. Posters were displayed at the start of the school year. Brochures describing the program and its goals were distributed to students in advance of the workshops, and personalized letters were sent to all parents of Grade 12 students to inform them about the workshops.

The LifeAfterHighSchool website could be accessed at any time with an account. In addition to material for the workshops, it contained links to additional financial resources (such as non-governmental scholarships and bursaries) and videos labelled 'True Stories' about the experiences of other young people who had applied and registered for postsecondary education programs across Ontario. 


\section{Implementation ${ }^{14}$}

Designing and implementing the LifeAfterHighSchool program involved making thousands of decisions. We paid attention to many small details, such as the content of each video, the hiring and training of facilitators, the design of posters and brochures, the script used for talking with principals and counselors, and the availability of on-site delivery and technical support. We also took measures to block web access to social media, ensure that internet bandwidth was sufficiently high during workshops, communicate with each schools' program coordinator, respond to early program feedback, avoiding students applying to programs and getting rejected, and obtain all useful data for analysis. With only one treatment arm in the first phase of the pilot and five additional treatment arms in the second phase (discussed in Section VI), knowing which of the other decisions mattered to the overall results is not possible. In cases where trade-offs may have existed, priority was given to making make the college application free, attractive, and more convenient for students at the margin of applying, while avoiding coming across as patronizing to any student.

Table 2 displays online workshop activity at program schools and provides some indication of the program fidelity. Panel A shows that a total of 11,356 students at the 43 program schools in 2011-12 had taken at least 4 years of high school. Only about half began the school year with at least 21 credits, which largely explains why only 6,950 Grade 12 students actually completed 30 credits by the end of the year to graduate and exit grade-school education. Panel B shows that 7,436 students created an account on the LifeAfterHighSchool website. While this is more than the total number of graduates that left high school that year, it is far

\footnotetext{
${ }^{14}$ More implementation details can be found in Reuben et al., 2016a
} 
fewer than the total number of Grade 12s who were eligible to participate in the program. There are a few possible explanations for this less-than-full participation. Counselors may have placed more emphasis on ensuring graduating seniors attended the workshops. There were portions of students for whom staff believed participation would not be appropriate, including students with learning disabilities and other special needs, and those who were in Grade 12 but who were far short of the number of credits required to graduate. Another explanation is that some students, when asked to move from a classroom to computer lab, went elsewhere. Others did not attend because they were not at school on the day of their scheduled workshop.

Conditional on creating a LifeAfterHighSchool account, participation in Workshop 1 was relatively high. Almost 90 percent of account holders worked at the 'Where Would You Go?' exercise and entered previous or expected grades, and almost half had time to try out the financial aid calculator after choosing their lists of programs of interest. Most importantly, a full three-quarters of LifeAfterHighSchool registered account holders used the site to pay for a college application (by entering their application number). Around half applied to 2-year community colleges, and the other half applied to 4-year universities.

A relatively small fraction of students in Workshop 3 emailed a parent or recorded their financial aid application numbers on our website. These outcomes may not be representative as indicators of overall participation because they were not required to actually complete the aid application. Still, other feedback from the field suggests there were limitations in trying to simplify the aid application process in class. A month delay in the launch of the online OSAP application form created scheduling challenges and led to Workshop 3 competing with many end-of-year activities. Guidance personnel reported that teachers were much less eager to allow their students to miss a class to attend the workshop, and students were also reluctant to do so, 
especially those who had not applied to college earlier. Students also needed to use their Social Insurance Numbers to open an OSAP account, and - despite emails sent to LifeAfterHighSchool account holders, letters sent to parents, and school reminders - many did not have them on hand. Students were instead given a paper version of the application and were encouraged to complete the form at home, or asked to follow-up with staff once they had obtained the information. Overall, 35 percent of school coordinators said that Workshop 3 attendance of graduating Grade 12 students was higher than 80 percent, and 55 percent said that attendance levels were at least 50 percent. In comparison, 80 and 70 percent of coordinators said that Workshop 1 and 2 attendances rates were at least 80 percent, respectively.

The overall reaction to LifeAfterHighSchool was quite positive. We surveyed 99 counselors, principals, and vice-principals from all 43 program schools about their perceptions of students' impressions of the program, and about their own perceptions. Respondents said that graduating students had high levels of interest in the program. A large majority said that graduating students found each workshop useful in helping them 1) locate a postsecondary program to apply for, 2) apply to a postsecondary program, and 3) understand the associated costs and benefits of postsecondary. Even for Workshop 3, 83 percent of respondents agreed that it helped students understand and apply for financial aid. Several educators noted that LifeAfterHighSchool had "kick-started" students' thinking about postsecondary education, helped them become more aware and informed about their options, and encouraged them to explore more programs and ask many more questions. Several respondents noted how this in turn had increased students' confidence about applying to postsecondary education and OSAP, and decreased related anxiety for both students and parents. 
Educators reported that they liked the resources and structure of the program. Some also implied the program had desirable behavioral effects. For example, some stated that having workshops in class time allowed counselors to ensure students received immediate or timely answers to their questions, "as opposed to [them] doing it at home and having to come to me for help the next day." Similarly, one said, "We went through the process as a group, so a sense of community, 'we're in this together' mindset was established - this provided some encouragement for our reluctant (less confident) students as well.” According to educators, this structured approach particularly helped students who were indecisive or lacked the confidence or motivation to engage in the application process, and those who were otherwise disadvantaged: "[LifeAfterHighSchool] forces students to start the process rather than relying on their initiative - [this is] especially helpful for those who don't have parents urging them to apply.”

Many counselors emphasized how important the payment of the application fee was to their students, many of whom lived in lower-income households. One Guidance Head said their application numbers were "way up", and another said, "This has been so great for our kids. I wish you could see our neighborhood — there are boarded up houses all over the place... For them to hear, 'you have potential, you can do this.' And when they saw the OSAP calculation, and realized, 'I can do this,' you should see their faces light up.”

\section{Data and Methodology}

The Ontario Ministry of Education keeps individual high school records on students in Grades 9 to 12 on a range of demographic and achievement variables. Individual level secondary 
and postsecondary application and registration data were linked at the Ministry of Education and made available for the purpose of analyzing the effectiveness of LifeAfterHighSchool. We received data for all Grade 12 students (with at least 4 years of high school) at program and control schools in the academic years 2009-10, 2010-11, 2011-12 (the year the program was administered), and 2012-13, including all of their associated achievement records for the academic years preceding and during their respective Grade 12 enrollment.

Three data sets were supplied, all linkable via a depersonalized student identification numbers. The first dataset comprised the Student Biographical File, with information on student gender, year of birth, whether a diploma was issued (and if so, when), and an indicator for students who were in Grade 12 for the first time. The second dataset was the Student Marks File, with information on each course taken, the credit value for each course, and the final course marks earned. The third file was the Student Application and Registration to Postsecondary Education in Ontario File, with information on the number of postsecondary applications filed each year and on any postsecondary registrations. "Registering” for a program means having paid the college tuition fees for the program (usually due by mid-September) and not dropping out by November 1st of the school year. For first-year students, being registered is very similar to being enrolled, since "enrollment” is a count of every student still registered in a program on November 1 . We therefore use registered and enrolled outcomes interchangeably. The linked file does not contain information on students who applied to colleges outside the province of Ontario, though this number is likely small.

Unfortunately, we were unable to obtain reliable information regarding who applied for financial aid. The OSAP application does not systematically collect information about an applicant's high school, nor does it require an applicant's Ontario Education Number, which 
could have been used to link with our files. The Ministry of Training, Colleges, and Universities tried to link their administrative data on OSAP recipients attending college with other data in order to identify students from our program and control schools, but researchers concluded that the match quality was too poor to be of use. Our main outcomes, therefore, are college program applications college enrollment, but not financial aid applications.

The main econometric model for estimating average program effects is the following randomized difference-in-differences model:

$$
Y_{i s c}=\delta_{s}+\delta_{c}+\beta T_{s c}+e_{i s c}
$$

where $Y_{i s c}$ is the outcome for student $i$, from school $s$, in the Grade 12 cohort $c$, and $T_{s c}$ is an indicator variable for whether LifeAfterHighSchool was administered at school $s$ for cohort $c$ and $e_{i s c}$ is the residual. For the 2011-12 cohort, since $T_{s c}$ was randomly assigned, estimating program effects by comparing differences in mean outcomes between program and control schools that year generates unbiased results. But with only 86 schools and school-level heterogeneity, we can increase precision by conditioning on prior school-level differences using school $\left(\delta_{s}\right)$ and cohort $\left(\delta_{c}\right)$ fixed effects, and by clustering standard errors at the school level.

Figure 2A displays this approach graphically. In the 2011-12 school year, the college application rate among graduating seniors from control schools was 65.4 percent. For program schools, the rate was 11.9 percentage points higher (77.3 percent). The standard error around this difference using student-level data is 2.5 percentage points. In the two years prior to LifeAfterHighSchool, application rates were slightly lower for program schools, though not by much (64.8 versus 66.0 percent). Taking these lower rates into account using equation (1) 
above, the estimated average program effect is an increase in application rates by 13.5 percentage points, with a standard error of 1.5 percentage points (a 40 percent decrease compared to the standard error using only one cohort). A similar pattern arises when looking at college enrollment rates in Figure 2B. The enrollment rate for graduating seniors in program schools in the program year was 5.3 percentage points higher than that for seniors in control schools (57.5 versus 52.2 percent with a standard error of 3.5 percentage points). Using equation (1) instead, the standard error is smaller at 1.3 percentage points, and the estimated effect is an increase in college enrollment by 5.0 percentage points.

Given the binary nature of our two main outcomes, we estimate equation (1) using a probit model, and present implied discrete changes in the probability of applying or enrolling in college due to receiving the program. Appendix Tables A3 and A4 present alternative estimates (which are similar to our main ones) using only the program year (comparing mean outcome differences), and using the randomized difference in differences approach but while also including the following linear control variables: a dummy for having taken university-track courses in high school interacted with high school grade average, number of credits earned at the start of a student's last year of high school, total number of courses failed in high school, age fixed effects, and dummy variables for gender, for taking university-track or workplace-track courses in grade 11, for whether the student was ever in special education classes, for being an immigrant, and for whether their mother tongue is neither French nor English.

We do not use subsequent cohorts as part of the estimating equation in case younger students benefit from having older schoolmates go through the program. Interestingly, we do not observe this impact: after the program ends in 2011-12, application and college enrollments 
rates for the next cohort of graduating seniors in program schools drop back to previous levels, similar to the observed rates for the next cohort of seniors in control schools.

\section{Results}

We begin by exploring whether LifeAfterHighSchool had any impact on high school outcomes. For example, it is possible that the program increased interest or awareness in postsecondary options, and led some seniors to strive for better grades, take different courses, or adjust their graduation plans. Table 3 shows estimated program effects on high school outcomes on all Grade 12 students using the randomized difference-in-differences approach outlined previously. The first column indicates the mean of the outcome variable for Grade 12 seniors in the control schools in 2011-12. The second column shows the estimated program effects, which are generally zero and insignificant. LifeAfterHighSchool caused no discernible change to the type of courses taken (e.g. university-track or college-track courses) or the number of courses taken. This is not surprising given that most students picked their course schedule well before the start of the first workshop. What is surprising is an estimated negative program effect on average grades (5 percent of a standard deviation lower). It is not clear why the program would have led to students performing worse. Given the 12 separate estimates in the table and the unintuitive direction of the effect, we suspect this result is due to chance.

The program also had no noticeable impact on time to high school completion or graduation outcomes. In the control group, the fraction of Grade 12 students that graduated by the end of the school year was 62.9 percent, and nearly all of them exited high school (53.2 
percent of all Grade 12s). Some stayed, along with other Grade 12s who did not satisfy enough requirements to graduate (30.9 percent stayed overall). The program effects on graduation and leaving high school are both estimated with small confidence bands around zero.

Table 4 shows the overall program effects of LifeAfterHighSchool on postsecondary application and enrollment rates. For reference, Columns 1, 3, and 5 list these rates for the control schools in the 2011-12 Grade 12 cohort. Among all Grade 12s, applications to any college or university increased 13.9 percentage points, relative to the control application rate of 39.5 percent. Most of this increase came from applications to 2-year colleges (a 10.4 percentage point increase compared to only a 3.6 percentage point increase in 4-year programs applications). The program did not significantly change the small rate at which students applied to both college and university application centers. Turning to enrollment, the program increased postsecondary attendance the following year by 2.9 percentage points among all Grade 12 students (with a standard error of 0.8 percentage points). As with the concentrated 2-year college application effects, all of the enrollment effects come from increased enrollment at 2year community colleges (with no increase in 4-year university enrollment).

These effects, averaged over the entire Grade 12 sample, are diminished by the fact that many students have not yet met graduation requirements, and stay in high school another year. Thus, in Columns 3 and 4, we condition on the pre-program characteristic of beginning Grade 12 with at least 21 credits. Students in this category are far more likely to graduate after taking a full course load than students with less than that amount. The overall college application rate effect for this group is slightly higher than that for the full sample, at 19.1 percentage points. As expected, enrollment effects is also higher, with an estimated increase in postsecondary 
attendance of 4.4. percentage points. This increase occurs almost exclusively through changes in community college enrollment.

Even for students that start the year with 21 credits, some fail courses and cannot graduate. Some may take a smaller load and spread their remaining courses over two years. And some may prefer to stay another year to take additional courses and increase their grade averages. Motivated by these cases and the earlier finding that the program had no impact on high school exit or graduation, the rest of our main results focus on the sample of students that left school with a high school certificate, since only these students could apply and go to college in the subsequent school year. ${ }^{15}$ For these Grade 12 graduates, LifeAfterHighSchool increased college applications by 13.6 percentage points (relative to the control group rate of 64.2 percent) and college enrollment by 5.2 percentage points (relative to the control group rate of 53.0 percent).

Table 5 shows applications and enrollment effects for different subgroups of exiting Grade 12 graduates. By gender, it is interesting to note the much higher application and enrollment rates for females over males -almost a 20 percentage point difference in both cases. The program effects by gender, however, are similar. College enrollment increases by 5.4 percentage points for males and 4.4 percentage points for females. Effects split by urban and rural high schools also lead to similar results: a 5.6 percentage point increase in enrollment at urban schools and a 4.6 percentage point increase at rural, although the rural estimate is less precisely estimated and significant only at the 10 percent level. ${ }^{16}$

\footnotetext{
${ }^{15}$ For sensitivity analysis, we also show the estimated program effects for the full sample and for students beginning Grade 12 with at least 21 credits, because these students are more likely to have met the requirements to graduate by the end of the year.

${ }^{16}$ A rural high school is defined as a high school with zero as its 2 nd alpha-numeric digit in its postal code, in line with Canada Post's definition.
} 
Ontario provides three types of courses in Grade 12 - university, college, and workplace which are catered to preparing students for these respective next destinations. University courses are more academic and theoretical, while College and Workplace courses are more applied. University programs in Ontario require at least some university-type course prerequisites. Most, but not all, Grade 12 graduates taking university-type courses applied and went to postsecondary the following year (83.0 and 70.3 percent respectively for the control group). Still, LifeAfterHighSchool raises application rates for these students by 7.9 percentage points, and enrollment by 3.6 percentage points. Fewer students without university-type courses applied and enrolled, but the program has a significantly larger impact on them. College application rates increase from 40.9 to 64.4 percent, and enrollment increases from 31.8 to 40.9 percent (a 9 percentage point increase). And for the small subset of students that take vocational-type courses in Grade 12 (1,753 out of 38,352),significantly limiting their postsecondary program options, LifeAfterHighSchool doubles relative application and enrollment rates (from 16.7 to 33.0 percent for application rates, and from 10.8 to 20.7 percent for enrollment).

Cut by grade average, LifeAfterHighSchool significantly affect three broad groups. Those with low Grade 12 grade averages - lower than 60 percent - see increases to application rates by 16 percentage points and enrollment rates by 5.8 percentage points. Those with grade averages at least 75 percent experience application increases from 77.7 to 88.6 percent and enrollment increases from 66.8 to 70.2 percent. The largest enrollment effects are for the group in the middle - with grade averages between 60 and 75 percent. Their enrollment effect is 6.4 percentage points. ${ }^{17}$

\footnotetext{
${ }^{17}$ This is notably larger than the impacts found in a rigorous evaluation of a popular academic program for US high schools that targets middle-achieving youth called AVID, that requires 3-4 years of weekly classroom time (Ford et al 2014)
} 
In summary, LifeAfterHighSchool was broadly influential in raising enrollment rates across all different types of students at low-transition high schools. It was impressively effective for students 'in the middle' - neither with above nor below-average grades, and neither taking courses that put them on a university or workplace trajectory.

\section{Phase Two ${ }^{18}$}

LifeAfterHighSchool increased Grade 12 college application rates from about 65 to 80 percent. From an operational perspective, these results were initially disappointing, since the goal of the program was to simplify the process to help virtually all exiting seniors to apply to and get accepted into at least one program they helped choose, and to secure financial aid packages. It is possible that the remaining 20 percent of students who did not apply never would, regardless of how simple the process was. On the other hand, given the implementation issues we experienced such as workshop absences and running out of time, perhaps we could have done better in helping these students become more interested in postsecondary options.

To explore this and a number of additional efficiency issues, the Ontario Ministry of Training, Colleges, and Universities supported our efforts to implement a second pilot two years later, which we call Phase II. We changed the baseline design of LifeAfterHighSchool to use wireless laptops, instead of school computer labs, so that we could better deliver the program in classrooms that students were supposed to be in. ${ }^{19}$ We also combined the first two workshops to deliver them simultaneously to all Grade 12s over an entire morning in the Fall. This reduced

\footnotetext{
${ }^{18}$ More operation and implementation details of Phase Two are provided in Ford et al. (2016b).

${ }^{19}$ Internet access was undertaken via Wifeless Hub Hotspots provided to each school.
} 
disruption and increased total workshop time by not having students transition between morning classes. Students were given headphones to proceed through choosing programs, learning more about financial aid, and applying at more of their own speed. Social media and other distracting websites were blocked. Another feature of the Phase II program is that it relied on third-party career planning software for helping students choose programs to apply. The 'Where Would You Go?' component of the program in Phase I that provided a list of local college options based on student grades and minimum requirements was deemed too expensive to redevelop, so instead we directed students to software already available in schools. As discussed, below, this may have altered the types of programs participants considered and applied for.

Phase II was also implemented to test four more variants of the program model for scaleup consideration. The first was 1) Baseline + 'Mop-up', in which paid facilitators returned to schools after the workshops to offer additional individual or small-group help to the students who had not completed their applications in class. This intervention was set up to explore how much more application rates would increase from providing additional support outside the workshops. The second was 2) Internal Staff + Fee Waivers, in which schools were provided access to the program web site and fee-waiver system, but not external support was provided to administer the program (including no laptops). This treatment arm was to explore whether school staff could be used to implement LifeAfterHighSchool instead of paid external facilitators. School staff were given instructions on how to implement the program, and were left on their own to do so. The third was 3) Baseline But No Fee Waiver, in which students received the full baseline program and external facilitator support, but were required to pay for college applications with credit or debit cards, or to ask their parents to do so. Since the largest cost item of the program was covering the approximate $\$ 100$ fee per student, the Ontario 
government wanted to test whether application rates would change if students received in-class assistance but were left to pay on their own. Finally, the fourth was 4) Internal Staff with No Fee Waiver, in which access to the LifeAfterHighSchool web site was made available but without fee waivers, and school staff were required to implement the program.

These variant models were tested by returning to 66 of the 86 Phase I schools (a smaller number for budget reasons). Rather than re-randomizing program and control groups, the original program schools were switched to control group status. We switched statuses (a) in order to still operate in the lowest-transition schools; (b) in order to avoid asking Phase I schools to implement modifications on the design they were used to (possibly asking them to no longer receive outside assistance or allow for fee waivers), and (c) after observing application rates fall back to control group levels between Phase I and Phase II (as displayed in Figure 2A). Statistical power in Phase II is lower than Phase I because of the smaller number of total schools and the smaller number of schools testing each variant (7 baseline schools, 4 in the Baseline + 'Mop-up' model, 5 for Internal Staff + Fee Waivers, 3 for Baseline But No Fee Waiver, and 9 for Internal Staff + No Fee Waiver). We employ the same randomized difference in differences methodology using additional data for the new treatment year (2013-14) and the two Grade 12 cohort years prior to Phase I treatment (2009-10 and 2010-11) to allow for school fixed effects.

Table 6 shows the different Phase II program effects on postsecondary applications for Grade 12 graduates leaving high school. ${ }^{20}$ The new baseline model met its goal of generating a larger application rate increase than the Phase I treatment did (a 19.3 percentage point compared to a 13.6 percentage point increase), although 16.0 percent of students still did not apply even under the new approach of entire morning workshops with laptops. Under the 'Baseline + 'Mop-

\footnotetext{
${ }^{20}$ Similar results for the sample of Grade 12 students beginning the year with at least 21 credits are shown in Appendix Tables A5 and A6.
} 
up'” model, when we provided facilitators to return to schools to offer additional assistance for students who had not applied during workshops, application rates increased 20.7 percentage points - only a marginal improvement to the estimated effect without 'Mop-up', and not a statistically significant difference. Encouragingly, school staff in the 'Internal Staff + No Fee Waivers' group were able to increase applications by as much or more than schools that were provided facilitators and laptops. In particular, applications for students with no university-track courses in Grade 12 increased by 38.7 percentage points - almost double - at schools with no external help. All three of these models also generated similar increases in applications for students taking university-track courses in Grade 12, and for students taking vocational courses.

But the Internal Staff + No Fee Waivers model did not fare as well. Offering application assistance while still requiring students to pay the $\$ 100$ fee had a zero, or even negative, impact on application rates. Perhaps students felt that the task they were being encouraged to do should have been free and became offended when they realized it was not. Or perhaps, after being notified about the program, parents relied more on the school to get their children through the process. The point estimates for college enrollment the following year at schools without fee waivers (shown in Table 6) are correspondingly negative and, in some cases, significant at the 10 percent confidence level. Removing application fees appears to be an important necessary condition for encouraging more students to apply.

Surprisingly, although Phase II models with fee waivers raised application rates more than Phase I effects, college enrollment effects were mostly not significantly different from zero. Table 7 shows these effects for the different Phase II treatment arms for Grade 12 graduates and other subgroups. The baseline estimated effect was -.036 with a standard error of 0.025 . The Baseline + 'Mop-up' effect was exactly zero with a standard error of 0.03 , and the estimate for 
the model with Internal staff + Fee waivers was 0.031 with a standard error of 0.37 . The combined sample generates an estimated effect within a 95 percent confidence interval of -4.1 to 2.6 percentage points. The only positively significant impact came from the schools with internal staff running the program and with fee waivers provided: for these schools, the main sample effect and the effect on students with no university-track courses (an 8.1 percentage point increase) were closest in line with the program effect estimates in Phase I.

The larger college application effects in Phase II juxtaposed against the smaller enrollment effects raises the interesting question, 'why the difference?'. One possibility is that the program effects are actually equal for all versions of LifeAfterHighSchool with fee waivers, and that we can obtain a more precise estimate by combining the two samples. Assuming this, the program effect is a 2.3 percentage point increase in enrollment, with a standard error of 1.0 percentage points. However, we easily reject equal effects $(0.044(\mathrm{se}=0.013)$ for Phase I, -0.007 (se=0.019) for Phase II), especially for the sample of students with no university-track courses (0.086 (se=0.016) for Phase I, $-0.011(\mathrm{se}=0.020)$ for Phase II). Another possibility is that economic conditions changed between the two treatment years, and students in Phase II were less interested in going to college. This also seems unlikely, since the province's unemployment rate fell only by .6 percentage points between the two years. ${ }^{21}$

A more plausible reason is that although Phase II further increased application rates, it may also have inadvertently affected the types of programs where students applied. One key difference between the two phases was the tool used for helping students choose where they might go. In Phase I, we asked students their grades and developed software to display a comprehensive list of local programs for which students would likely be accepted; in contrast, in Phase II we relied on external software that required students to sift through programs based on

\footnotetext{
${ }^{21}$ From Statistics Canada's Labour Force Survey: 7.9 percent in 2012 and 7.3 percent in 2014.
} 
their career interests. To explore whether this made a difference to where students applied, we make use of available data separating 2- and 4-year colleges (we do not have data on program of study). Table 8 shows estimated effects for Phase I and Phase II designs (that included fee waivers), separated by whether students took university-level or vocational courses in Grade 12 and whether effects are for 2- or 4-year programs. Among students taking no university-level courses, the entire application impact was on 2-year colleges and not 4-year colleges. The higher application rate increase in Phase II also led to a proportional increase in 2-year applications. The same happened for students with only vocational courses - all of the increase in overall application rates was driven by increases in 2-year college applications, which is reassuring since these students were unlikely to be accepted to any university programs.

In contrast, Phase I and Phase II application effects differ for students with universitylevel courses. In Phase I, both 2- and 4-year college applications increased for students with university-level courses (by 3.7 and 6.7 percentage points respectively), but in Phase II, only applications to 4-year colleges increased significantly (by 14.2 percentage points). We also observe a significant decrease in 2-year college enrollment for these students [-0.049 $(\mathrm{se}=0.018)]$ and an offsetting increase in 4-year enrollment [0.036 (se=0.027)]. The greater emphasis Phase II appears to have placed on 4-year colleges may have led students to submit applications to programs that were subsequently rejected from, or to programs from which they received offers and declined.

We do not have information on application rejections at the 4-year postsecondary level, but we do at the 2-year level from the Ontario College Application Service (OCAS). Table 9 shows estimated Phase I and II program effects for the total number of students in a school who applied to a 2-year college, applied and received at least one offer, applied and received no 
offers, and applied and accepted one offer. In Panel A, the outcome (at the school-year level) is regressed on a treatment dummy, along with cohort and program school fixed effects, weighted by Grade 12 school size. For Phase I, the cohorts are 2009/10, 2010/11, and 2011/12 (the year of treatment). For Phase II, the cohort years are 2009/10, 2010/11, and 2013/14 (the year treated). In Panel B, the outcome variables are divided by Grade 12 school size (the number of Grade 12s in each school, calculated from Ministry of Education data) to convert the estimated effects into percentage point changes.

LifeAfterHighSchool in Phase I, on average, increased applications to 2-year colleges by 35 students per school, and following-year college enrollment by 15 students per school. This translates to an estimated increase in applications by 9 percentage points and in enrollment by 3.4 percentage points, which is very similar to the results reported in Table 4 (which used Ministry of Education Data). Importantly, Phase I did not significantly affect the number of students applying and receiving no offers. In contrast, although we estimate that Phase II increased the fraction of college applications by more than in Phase I, some of these additional applications were rejected. On average, Phase II increased the number of students who applied but received no offers by 11 per school, or 3.3 percentage points.

In short, relatively small changes in implementation of LifeAfterHighSchool successfully increased college application rates even further, but may also have altered the types of programs participants considered and applied for. Supporting evidence includes the finding that, for Phase II university-track students, application effects were driven only by increases in 4-year college applications, whereas we saw no subsequent enrollment effects in Phase I or II. For nonuniversity track students, more students applied due to exposure to the Phase II over Phase I program, but some of these additional applicants were rejected. Guidance in choosing programs 
that will accept students, along with application fee waivers, therefore appear to be important prerequisites for successfully helping with the college transition.

\section{Conclusion}

This paper presents results from a school-level randomized trial evaluating a new program that incorporates college application assistance directly into the high school classroom activities. Students at low-transition schools are encouraged to keep options open by going through the actual application process. Those who do may realize a variety of programs of interest exist that they were not initially aware of, or become more informed about college costs and opportunities. Over three classes, students were guided to choose college programs they would likely be eligible for, shown a basic college budget and financial aid calculator, given help applying without having to pay the fee, and introduced to the financial aid application (with follow-up requests sent to parents). Among all Grade 12 graduates, the program increased program application rates by 13 percentage points, and college enrollment rates by about 5 percentage points. Impacts were concentrated among those not already taking university-track courses.

These results are quite comparable to those of studies examining other ways to simplify the college transition. In the FAFSA study by Bettinger et al. (2012), low-income parents who went to H\&R Block received assistance in completing their Grade 12 child's financial aid application, and were provided information about local colleges. Application rates and college enrollment increased by 15 and 8 percentage points, respectively. Another study by Carrell and 
Sacerdote (2013) involved counselors identifying particular Grade 12 students as possible beneficiaries from receiving individual support with undergraduate students to help and encourage them through all application steps, along with application fee waivers. Program applications increased 29 percentage points and college enrollment 5 percentage points. Castleman and Page (2015) examined sending text reminders and offering phone-support for getting through remaining college transition tasks over the summer. Fall enrollment rates for recent high school graduates who had at least started the FAFSA increased, on average, by 3 percentage points. A related study by Hoxby and Turner (2013) looked at helping disadvantaged students with high SAT scores transition to more selective schools. Mailing these Grade 12 students suggestions for selective schools they were likely to be accepted into, along with fee waiver vouchers, increased the number of applications sent and the enrollment rate at more selective colleges by 5 percentage points.

Collectively, these studies clearly demonstrate that complexity and lack of support in the college transition process affect whether some individuals enroll or not. It remains to be seen whether those affected by simplifying the transition benefit. We cannot tell for sure at the individual level or even the average level since no experiment has yet looked at longer-term outcomes like arnings. But the finding that low-cost assistance matters suggests for some students enrollment decisions do not represent well-thought-out investments decisions. Reviews of existing research on returns to higher education suggests high rates of return to college, even for marginal students (Oreopoulos and Peteronjevic, 2013, Hout, 2012, Barrow and Malamud, 2015). ${ }^{22}$ The FAFSA study also shows students than enrolled in

\footnotetext{
${ }^{22}$ http://www.annualreviews.org/doi/full/10.1146/annurev.soc.012809.102503, http://www.annualreviews.org/doi/abs/10.1146/annurev-economics-080614-115510
} 
college because of the program persisted into second year and had to navigate subsequent financial aid and registration requirements on their own.

To maintain even an option of going to college when exiting high school, students must get through the application process. How best to help students do so depends on context and feasibility. Some changes, like sending text reminders, are relatively straightforward to introduce without significant disruption to the process' existing framework. Other changes, like using parental income information from tax files instead of asking for it on applications, require reinvention and even new legislation. Small details matter as well: our inability to assist some students in opening a financial aid application because they did not have on hand their Social Insurance Number is but one example; not being able to assist all Grade 12s in class at the same time is another. We also learned that waiving application fees is an important necessary condition for making in-class assistance worthwhile, as students were not willing to respond to in-class support if required to pay to submit an application. Clearly the effectiveness of a program in simplifying the application process depends on addressing multiple potential bottlenecks simultaneously.

Personalization matters too, as we learned from implementing LifeAfterHighSchool a second time. Completing the financial aid application only involves answering factual questions, but completing the program application involves considering what programs will accept and interest students. The degree of personal assistance in helping students find suitable programs to apply seems to make a large difference for actual enrollment outcomes. Students given a succinct set of program options that would accept them if they applied were much more likely to later enroll than those left to consider minimum requirements on their own. Other personalized 
variants of the program, such as adding follow-up text reminders, may also be useful and could be evaluated based on cost-effectiveness, operational feasibility, and experience.

For schools that wish to offer in-class college transition assistance, the LifeAfterHighSchool experiments suggest two starting points. Firstly, waiving application fees for at least the first 3 applications can be very helpful and encouraging for students, especially those in low-transition schools. Secondly, a simple 'one-stop' website that guides students and parents through each step (including identifying best program matches, and help with the financial aid process) can be helpful in simplifying and de-mystifying the application process. These two changes could enable high schools to incorporate effective application assistance during class time, and help students keep the “college option” open. 


\section{References}

Advisory Committee on Student Financial Assistance. (2005). The Student Aid Gauntlet: Making Access to College Simple and Certain: Final Report of the Special Study of Simplification of Need Analysis and Application for Title IV Aid. Advisory Committee on Student Financial Assistance, Washington, DC.

Barrow, L., \& Malamud, O. (2015). Is College a Worthwhile Investment? Annual Review of Economics, 7(1), 519-555.

Beshears, J., Choi, J. J., Laibson, D., \& Madrian, B. C. (2013). Simplification and saving. Journal of Economic Behavior \& Organization, 95, 130-145.

Bettinger, E. P., Long, B. T., Oreopoulos, P., \& Sanbonmatsu, L. (2012). The role of application assistance and information in college decisions: Results from the H\&R block FAFSA experiment. The Quarterly Journal of Economics, 127(3), 1205-1242.

Carrell, S. E., \& Sacerdote, B. (2013). Late interventions matter too: The case of college coaching New Hampshire (No. w19031). Cambridge, MA: National Bureau of Economic Research.

Carroll, Gabriel D., James J. Choi, David Laibson, Brigitte C. Madrian, and Andrew Metrick. 2009. “Optimal Defaults and Active Decisions.” The Quarterly Journal of Economics, 124 (4): 1639-1674.

Castleman, B. L., \& Page, L. C. (2015). Summer nudging: Can personalized text messages and peer mentor outreach increase college going among low-income high school graduates?. Journal of Economic Behavior \& Organization, 115, 144-160.

Chetty, R., Friedman, J. N., Leth-Petersen, S., Nielsen, T., \& Olsen, T. (2014). Active vs. passive decisions and crowdout in retirement savings accounts: Evidence from Denmark. The Quarterly Journal of Economics, 129(3), 1141-1219.

Frederick, S., Loewenstein, G., \& O'donoghue, T. (2002). Time discounting and time preference: A critical review. Journal of Economic Literature, 40(2), 351-401.

Hout, M. (2012). Social and economic returns to college education in the United States. Annual Review of Sociology, 38, 379-400.

Hoxby, C., \& Turner, S. (2013). Expanding college opportunities for high-achieving, low income students. Stanford Institute for Economic Policy Research Discussion Paper, (12-014).

Kable, J. W., \& Glimcher, P. W. (2007). The neural correlates of subjective value during intertemporal choice. Nature neuroscience, 10(12), 1625-1633. 
Kable, J. W., \& Glimcher, P. W. (2010). An "as soon as possible” effect in human intertemporal decision making: behavioral evidence and neural mechanisms. Journal of Neurophysiology, 103(5), 2513-2531.

Lavecchia, A. M., Liu, H., \& Oreopoulos, P. (2014). Behavioral economics of education: Progress and possibilities (No. w20609). National Bureau of Economic Research.

McClure, S. M., Laibson, D. I., Loewenstein, G., \& Cohen, J. D. (2004). Separate neural systems value immediate and delayed monetary rewards. Science, 306(5695), 503-507.

Oreopoulos, P., \& Dunn, R. (2013). Information and College Access: Evidence from a Randomized Field Experiment. The Scandinavian Journal of Economics, 115(1), 3-26.

Oreopoulos, P., \& Petronijevic, U. (2013). Making college worth it: A review of the returns to higher education. The Future of Children, 23(1), 41-65.

Reuben, E., Sapienza, P., \& Zingales, L. (2014). How stereotypes impair women's careers in science. Proceedings of the National Academy of Sciences, 111(12), 4403-4408.

Rosenberg, T. (2016, April 26). Guiding a first generation to college. The New York Times. Retrieved from http://opinionator.blogs.nytimes.com/2016/04/26/guiding-a-first-generation-tocollege/?_r $=0$

Stanovich, K. E., West, R. F., \& Toplak, M. E. (2012). Judgment and decision making in adolescence: Separating intelligence from rationality. American Psychological Association, xviii, 337-378.

Statistics Canada. No date. Labour force characteristics (table). Summary Tables. Last updated January 8, 2016. Retrieved from http://www.statcan.gc.ca/tables-tableaux/sumsom/101/cst01/econ10-eng.htm

U.S. Bureau of Labor Statistics. (2016, April 28). College enrollment and work activity of high school graduates. Retrieved from http://www.bls.gov/bls/newsrels.htm 
Table 1

Descriptive Statistics for Program and Control Schools

2010-11 (one year before program was introduced)

\begin{tabular}{|c|c|c|c|c|}
\hline & \multicolumn{2}{|c|}{ All Grade 12 Students } & \multicolumn{2}{|c|}{ Graduating Grade 12 Students } \\
\hline & $\begin{array}{c}\text { Control School } \\
\text { Mean }\end{array}$ & $\begin{array}{c}\text { Program School } \\
\text { Difference }\end{array}$ & $\begin{array}{c}\text { Control School } \\
\text { Mean }\end{array}$ & $\begin{array}{c}\text { Program School } \\
\text { Difference }\end{array}$ \\
\hline Grade 12 Grade Average & 64.664 & $\begin{array}{l}-0.238 \\
{[1.464]}\end{array}$ & 72.745 & $\begin{array}{c}0.951 \\
{[0.790]}\end{array}$ \\
\hline Taking University-Track Courses & 0.459 & $\begin{array}{l}-0.016 \\
{[0.037]}\end{array}$ & 0.577 & $\begin{array}{c}0.016 \\
{[0.034]}\end{array}$ \\
\hline At least 21 credits at start of Grade 12 & 0.57 & $\begin{array}{l}-0.027 \\
{[0.041]}\end{array}$ & 0.766 & $\begin{array}{l}-0.007 \\
{[0.030]}\end{array}$ \\
\hline Fraction Female & 0.458 & $\begin{array}{c}0.011 \\
{[0.010]}\end{array}$ & 0.501 & $\begin{array}{c}0.01 \\
{[0.012]}\end{array}$ \\
\hline Age & 18.885 & $\begin{array}{c}-0.098 \\
{[0.280]}\end{array}$ & 18.635 & $\begin{array}{c}-0.09 \\
{[0.093]}\end{array}$ \\
\hline Home Language Not English & 0.08 & $\begin{array}{l}-0.001 \\
{[0.036]}\end{array}$ & 0.069 & $\begin{array}{c}0 \\
{[0.030]}\end{array}$ \\
\hline Received High School Certificate & 0.636 & $\begin{array}{c}-0.041 \\
{[0.031]}\end{array}$ & 1 & \\
\hline Took Additional Years of High School & 0.318 & $\begin{array}{c}0.018 \\
{[0.018]}\end{array}$ & 0 & \\
\hline Graduated and Left High School & 0.524 & $\begin{array}{l}-0.035 \\
{[0.027]}\end{array}$ & 1 & \\
\hline Applied to Postsecondary Program & 0.389 & $\begin{array}{l}-0.025 \\
{[0.026]}\end{array}$ & 0.658 & $\begin{array}{l}-0.006 \\
{[0.026]}\end{array}$ \\
\hline Applied to College Program & 0.223 & $\begin{array}{l}-0.022 \\
{[0.016]}\end{array}$ & 0.376 & $\begin{array}{l}-0.023 \\
{[0.020]}\end{array}$ \\
\hline Applied to University Program & 0.194 & $\begin{array}{l}-0.007 \\
{[0.022]}\end{array}$ & 0.33 & $\begin{array}{c}0.012 \\
{[0.033]}\end{array}$ \\
\hline Enrolled in Postsecondary Program & 0.295 & $\begin{array}{l}-0.022 \\
{[0.022]}\end{array}$ & 0.545 & $\begin{array}{l}-0.007 \\
{[0.025]}\end{array}$ \\
\hline Enrolled in College Program & 0.159 & $\begin{array}{l}-0.019 \\
{[0.013]}\end{array}$ & 0.29 & $\begin{array}{c}-0.02 \\
{[0.018]}\end{array}$ \\
\hline Enrolled in University Program & 0.136 & $\begin{array}{l}-0.003 \\
{[0.016]}\end{array}$ & 0.255 & $\begin{array}{c}0.014 \\
{[0.028]}\end{array}$ \\
\hline Number of Grade 12 Students & 380.969 & $\begin{array}{l}-35.387 \\
{[35.525]}\end{array}$ & 203.709 & $\begin{array}{l}-24.917 \\
{[21.290]}\end{array}$ \\
\hline Number of Schools & 43 & 43 & 43 & 43 \\
\hline
\end{tabular}

Notes: Data are from Ontario Ministry of Education student records linked, aggregated at the school level for LifeAfterHighSchool treated and control schools. The first two columns show control means, weighted by school size, and program differences for the sample of all students with at least 4 years of high school. The last two columns show control means and program differences for the sample of students that exited high school by the following year with a high school degree. Standard errors for the difference between program and control school means are shown in square brackets (none of which are statistically significant at the 10 percent level or less). 
Table 2

Online Workshop Activity at Program Schools

\begin{tabular}{|c|c|c|c|}
\hline A. Ministry of Education Data & & $\begin{array}{c}\text { Fraction of All } \\
\text { Grade } 12 \text { Students }\end{array}$ & $\begin{array}{l}\text { Fraction of Online } \\
\text { Account Holders }\end{array}$ \\
\hline Total Grade 12 Students at Program Schools & 11356 & & \\
\hline Beginning with at least 21 credits & 6336 & 0.558 & \\
\hline Graduated and left immediately following school year & 6950 & 0.612 & \\
\hline Applied to college & 3499 & 0.308 & \\
\hline Applied to university & 2640 & 0.232 & \\
\hline Applied to any postsecondary program & 5749 & 0.506 & \\
\hline \multicolumn{4}{|l|}{ B. Website Data } \\
\hline \multicolumn{4}{|l|}{ Workshop 1 Activities } \\
\hline Registered account & 7436 & 0.655 & 1.000 \\
\hline Entered previous courses taken and grades & 6500 & 0.572 & 0.874 \\
\hline Identified at least one favorite program & 4807 & 0.423 & 0.646 \\
\hline Identified fav. program and tried aid calculator & 3457 & 0.304 & 0.465 \\
\hline \multicolumn{4}{|l|}{ Workshop 2 Activities } \\
\hline Applied to college & 2869 & 0.253 & 0.386 \\
\hline Applied to university & 2670 & 0.235 & 0.359 \\
\hline Applied to any postsecondary program & 5539 & 0.488 & 0.745 \\
\hline \multicolumn{4}{|l|}{ Workshop 3 Activities } \\
\hline Entered application Number for Storage & 940 & 0.083 & 0.126 \\
\hline Follow-up email sent to parent & 573 & 0.050 & 0.077 \\
\hline
\end{tabular}

Notes: Panel A reports student counts from Ministry of Education student records for program schools in the year of being treated. Panel B reports counts of students registered on the LifeAfterHighSchool website and recorded activity on that website in relation to the program's three workshops. See text for more details. 
Table 3

Estimated Program Effect on Average High School Outcomes for All Grade 12 Students

\begin{tabular}{|c|c|c|}
\hline & $\begin{array}{l}\text { Control School } \\
\text { Mean in } \\
2011 / 12\end{array}$ & $\begin{array}{l}\text { Treated School } \\
\text { Mean Difference } \\
\text { [standard error] }\end{array}$ \\
\hline Gr12 Course Credits Earned & $\begin{array}{c}4.9 \\
(s d=3.37)\end{array}$ & $\begin{array}{c}-0.043 \\
{[0.068]}\end{array}$ \\
\hline Taking Gr12 college or university-track courses & 0.503 & $\begin{array}{c}-0.016 \\
{[0.013]}\end{array}$ \\
\hline Taking Gr12 university-track English & 0.294 & $\begin{array}{c}-0.004 \\
{[0.009]}\end{array}$ \\
\hline Taking Gr12 college-track English & 0.324 & $\begin{array}{c}0.011 \\
{[0.009]}\end{array}$ \\
\hline Taking Gr12 university-track math & 0.323 & $\begin{array}{c}-0.006 \\
{[0.008]}\end{array}$ \\
\hline Taking Gr12 college-track math & 0.169 & $\begin{array}{c}0.004 \\
{[0.009]}\end{array}$ \\
\hline Taking Any Gr12 science course & 0.418 & $\begin{array}{c}0.005 \\
{[0.008]}\end{array}$ \\
\hline $70 \%$ or more in $\mathrm{Gr} 12$ science course & 0.276 & $\begin{array}{c}0.005 \\
{[0.007]}\end{array}$ \\
\hline Average Gr12 grade & $\begin{array}{c}64.7 \\
(s d=20.6)\end{array}$ & $\begin{array}{c}-1.079 \\
{[0.448]^{* *}}\end{array}$ \\
\hline Graduated and left immediately following school year & 0.629 & $\begin{array}{c}-0.012 \\
{[0.012]}\end{array}$ \\
\hline Took additional high school & 0.309 & $\begin{array}{c}-0.006 \\
{[0.010]}\end{array}$ \\
\hline Left school with high school certificate & 0.532 & $\begin{array}{c}0.004 \\
{[0.011]}\end{array}$ \\
\hline
\end{tabular}

Notes: Data are from Ontario Ministry of Education student records. The sample of 75,032 students includes all students with at least 4 years of high school at program and control schools in 2009/10, 2010/11 and 2011/12 (the year treated). The control mean reported is for the 2011/12 year. The effects are estimated from a probit model of the outcome variable regressed on a treatment dummy, along with fixed effects for cohort year and school. Marginal effects at mean values are reported. Standard errors are clustered by school and shown in square brackets. $\mathrm{sd}=$ standard deviation. $*, * *$, and $* * *$ indicate statistical significance at the 10,5 , and 1 percent levels respectively. 
Table 4

Estimated Program Effect on the Probability a Student Applied to or Enrolled in a Postsecondary Program

\begin{tabular}{|c|c|c|c|c|c|c|}
\hline & \multicolumn{6}{|c|}{ Students Beginning Grade 12} \\
\hline & \multicolumn{2}{|c|}{ All Grade 12 Students } & \multicolumn{2}{|c|}{ With $>=21$ Credits } & \multicolumn{2}{|c|}{ Grade 12 Graduates } \\
\hline & $\begin{array}{l}\text { Control } \\
\text { Mean }\end{array}$ & $\begin{array}{l}\text { Program } \\
\text { Difference }\end{array}$ & $\begin{array}{l}\text { Control } \\
\text { Mean }\end{array}$ & $\begin{array}{l}\text { Program } \\
\text { Difference }\end{array}$ & $\begin{array}{l}\text { Control } \\
\text { Mean }\end{array}$ & $\begin{array}{l}\text { Program } \\
\text { Difference }\end{array}$ \\
\hline Applied to College or University & 0.395 & $\begin{array}{c}0.139 \\
{[0.013]^{* * *}}\end{array}$ & 0.561 & $\begin{array}{c}0.191 \\
{[0.016]^{* * *}}\end{array}$ & 0.642 & $\begin{array}{c}0.136 \\
{[0.014]^{* * *}}\end{array}$ \\
\hline Applied to College & 0.227 & $\begin{array}{c}0.104 \\
{[0.011]^{* * *}}\end{array}$ & 0.303 & $\begin{array}{c}0.137 \\
{[0.014]^{* * *}}\end{array}$ & 0.365 & $\begin{array}{c}0.125 \\
{[0.013]^{* * *}}\end{array}$ \\
\hline Applied to University & 0.2 & $\begin{array}{c}0.036 \\
{[0.008]^{* * *}}\end{array}$ & 0.304 & $\begin{array}{c}0.063 \\
{[0.011]^{* * *}}\end{array}$ & 0.319 & $\begin{array}{c}0.023 \\
{[0.013]^{*}}\end{array}$ \\
\hline Applied to College and University & 0.321 & $\begin{array}{c}0.004 \\
{[0.003]}\end{array}$ & 0.047 & $\begin{array}{c}0.006 \\
{[0.005]}\end{array}$ & 0.048 & $\begin{array}{c}0.007 \\
{[0.006]}\end{array}$ \\
\hline Enrolled in College or University & 0.301 & $\begin{array}{c}0.029 \\
{[0.008]^{* * *}}\end{array}$ & 0.443 & $\begin{array}{c}0.044 \\
{[0.013]^{* * *}}\end{array}$ & 0.53 & $\begin{array}{c}0.052 \\
{[0.013]^{* * *}}\end{array}$ \\
\hline Enrolled in College & 0.166 & $\begin{array}{c}0.029 \\
{[0.006]^{* * *}}\end{array}$ & 0.231 & $\begin{array}{c}0.038 \\
{[0.010]^{* * *}}\end{array}$ & 0.284 & $\begin{array}{c}0.05 \\
{[0.010]^{* * *}}\end{array}$ \\
\hline Enrolled in University & 0.136 & $\begin{array}{c}0 \\
{[0.006]}\end{array}$ & 0.213 & $\begin{array}{c}0.007 \\
{[0.008]}\end{array}$ & 0.238 & $\begin{array}{c}0.002 \\
{[0.012]}\end{array}$ \\
\hline Total Sample Size & & 75,030 & & 41,645 & & 38,130 \\
\hline
\end{tabular}

Notes: Data are from Ontario Ministry of Education student records. The sample includes students with at least 4 years of high school at program and control schools in 2009/10, 2010/11 and 2011/12 (the year treated). The control mean reported is for the 2011/12 year. The increase in probability of applying or enrolling from exposure to the program is estimated from a probit model of the outcome variable regressed on a treatment dummy, along with fixed effects for cohort year and school. Marginal effects at mean values are reported. Standard errors are clustered by school and shown in square brackets. ${ }^{*}, * *$, and ${ }^{* * *}$ indicate statistical significance at the 10,5 , and 1 percent levels respectively. 
Table 5

Estimated Program Effect on Grade 12 Graduates by Subgroup

\begin{tabular}{|c|c|c|c|c|c|}
\hline & \multicolumn{2}{|c|}{$\begin{array}{c}\text { Applied to Postsecondary } \\
\text { Program }\end{array}$} & \multicolumn{2}{|c|}{$\begin{array}{l}\text { Enrolled in Postsecondary } \\
\text { Program }\end{array}$} & \multirow[t]{2}{*}{$\begin{array}{l}\text { Sample } \\
\text { Size }\end{array}$} \\
\hline & $\begin{array}{l}\text { Control } \\
\text { Mean }\end{array}$ & $\begin{array}{l}\text { Program } \\
\text { Difference }\end{array}$ & $\begin{array}{c}\text { Control } \\
\text { Mean }\end{array}$ & $\begin{array}{l}\text { Program } \\
\text { Difference }\end{array}$ & \\
\hline Males & 0.568 & $\begin{array}{c}0.145 \\
{[0.022]^{* * *}}\end{array}$ & 0.463 & $\begin{array}{c}0.054 \\
{[0.018]^{* * *}}\end{array}$ & 18,978 \\
\hline Females & 0.743 & $\begin{array}{c}0.122 \\
{[0.012]^{* * *}}\end{array}$ & 0.624 & $\begin{array}{c}0.044 \\
{[0.017]^{* * *}}\end{array}$ & 19,374 \\
\hline Urban Schools & 0.65 & $\begin{array}{c}0.135 \\
{[0.015]^{* * *}}\end{array}$ & 0.539 & $\begin{array}{c}0.05 \\
{[0.015]^{* * *}}\end{array}$ & 32,832 \\
\hline Rural Schools & 0.668 & $\begin{array}{c}0.135 \\
{[0.024]^{* * *}}\end{array}$ & 0.553 & $\begin{array}{c}0.046 \\
{[0.025]^{*}}\end{array}$ & 5,520 \\
\hline $\begin{array}{l}\text { Taking At Least One Gr12 } \\
\text { University Track Course }\end{array}$ & 0.83 & $\begin{array}{c}0.079 \\
{[0.010]^{* * *}}\end{array}$ & 0.703 & $\begin{array}{c}0.036 \\
{[0.014]^{* *}}\end{array}$ & 22,226 \\
\hline $\begin{array}{l}\text { Taking No Gr12 } \\
\text { University Track Course }\end{array}$ & 0.409 & $\begin{array}{c}0.235 \\
{[0.020]^{* * *}}\end{array}$ & 0.318 & $\begin{array}{c}0.091 \\
{[0.017]^{* * *}}\end{array}$ & 16,126 \\
\hline $\begin{array}{l}\text { Taking Gr12 Vocational } \\
\text { Math or English }\end{array}$ & 0.167 & $\begin{array}{c}0.33 \\
{[0.069]^{* * *}}\end{array}$ & 0.108 & $\begin{array}{c}0.099 \\
{[0.051]^{*}}\end{array}$ & 1,753 \\
\hline $\begin{array}{l}\text { Taking No Gr12 } \\
\text { Vocational Math or English }\end{array}$ & 0.681 & $\begin{array}{c}0.129 \\
{[0.013]^{* * *}}\end{array}$ & 0.566 & $\begin{array}{c}0.05 \\
{[0.013]^{* * *}}\end{array}$ & 36,599 \\
\hline Grade Average $<60 \%$ & 0.413 & $\begin{array}{c}0.166 \\
{[0.034]^{* * *}}\end{array}$ & 0.3 & $\begin{array}{c}0.058 \\
{[0.026]^{* *}}\end{array}$ & 5,150 \\
\hline Grade Average Btw. 60-75\% & 0.598 & $\begin{array}{c}0.156 \\
{[0.018]^{* * *}}\end{array}$ & 0.483 & $\begin{array}{c}0.064 \\
{[0.018]^{* * *}}\end{array}$ & 16,777 \\
\hline Grade Average $>=75 \%$ & 0.777 & $\begin{array}{c}0.109 \\
{[0.010]^{* * *}}\end{array}$ & 0.668 & $\begin{array}{c}0.044 \\
{[0.017]^{* * *}}\end{array}$ & 16,425 \\
\hline
\end{tabular}

Notes: Same as in Table 4. 
Table 6

Phase II Program Effects on Postsecondary Application Rates for Grade 12 Graduates

\begin{tabular}{|c|c|c|c|c|}
\hline Program Design & $\begin{array}{c}\text { Full Sample } \\
\text { (control mean }=0.627)\end{array}$ & $\begin{array}{c}\text { No G12 } \\
\text { Univ. Track Courses } \\
\text { (control mean }=0.401 \text { ) }\end{array}$ & $\begin{array}{c}\text { Took At Least } 1 \\
\text { G12 Univ. Course } \\
\text { (control mean }=0.762 \text { ) }\end{array}$ & $\begin{array}{c}\text { Took At Least } 1 \\
\text { Vocational Course } \\
\text { (control mean }=0.212 \text { ) }\end{array}$ \\
\hline Baseline & $\begin{array}{c}0.193 \\
{[0.024]^{* * *}}\end{array}$ & $\begin{array}{c}0.288 \\
{[0.033]^{* * *}}\end{array}$ & $\begin{array}{c}0.132 \\
{[0.019]^{* * *}}\end{array}$ & $\begin{array}{c}0.282 \\
{[0.085]^{* * *}}\end{array}$ \\
\hline $\begin{array}{l}\text { Baseline + } \\
\text { "Mop-up" }\end{array}$ & $\begin{array}{c}0.207 \\
{[0.023]^{* * *}}\end{array}$ & $\begin{array}{c}0.294 \\
{[0.052]^{* * *}}\end{array}$ & $\begin{array}{c}0.135 \\
{[0.010]^{* * *}}\end{array}$ & $\begin{array}{c}0.475 \\
{[0.112]^{* * *}}\end{array}$ \\
\hline $\begin{array}{l}\text { Internal Staff + } \\
\text { Fee waivers }\end{array}$ & $\begin{array}{c}0.236 \\
{[0.093]^{* *}}\end{array}$ & $\begin{array}{c}0.387 \\
{[0.111]^{* * *}}\end{array}$ & $\begin{array}{c}0.145 \\
{[0.063]^{* *}}\end{array}$ & $\begin{array}{c}0.207 \\
{[0.217]}\end{array}$ \\
\hline $\begin{array}{l}\text { Baseline with } \\
\text { No fee waiver }\end{array}$ & $\begin{array}{l}-0.041 \\
{[0.050]}\end{array}$ & $\begin{array}{c}-0.137 \\
{[0.038]^{* * *}}\end{array}$ & $\begin{array}{c}0.021 \\
{[0.021]}\end{array}$ & $\begin{array}{l}-0.033 \\
{[0.042]}\end{array}$ \\
\hline $\begin{array}{l}\text { Internal Staff with } \\
\text { No fee waiver }\end{array}$ & $\begin{array}{l}-0.038 \\
{[0.026]}\end{array}$ & $\begin{array}{l}-0.018 \\
{[0.045]}\end{array}$ & $\begin{array}{c}-0.046 \\
{[0.026]^{*}}\end{array}$ & $\begin{array}{l}-0.003 \\
{[0.049]}\end{array}$ \\
\hline $\begin{array}{l}\text { All schools with } \\
\text { Fee waivers }\end{array}$ & $\begin{array}{c}0.204 \\
{[0.022]^{* * *}}\end{array}$ & $\begin{array}{c}0.301 \\
{[0.031]^{* * *}}\end{array}$ & $\begin{array}{c}0.136 \\
{[0.017]^{* * *}}\end{array}$ & $\begin{array}{c}0.319 \\
{[0.078]^{* * *}}\end{array}$ \\
\hline $\begin{array}{l}\text { All schools with } \\
\text { No fee waiver }\end{array}$ & $\begin{array}{l}-0.039 \\
{[0.025]}\end{array}$ & $\begin{array}{l}-0.055 \\
{[0.040]}\end{array}$ & $\begin{array}{c}-0.03 \\
{[0.024]}\end{array}$ & $\begin{array}{l}-0.016 \\
{[0.040]}\end{array}$ \\
\hline $\begin{array}{l}\text { Sample Size for All } \\
\text { Schools with Fee }\end{array}$ & ivers & 10,598 & 15,732 & 1,747 \\
\hline
\end{tabular}

Notes: Data are from Ontario Ministry of Education student records. The sample includes students with at least 4 years of high school at program and control schools in 2009/10, 2010/11 and 2013/14 (the year Phase II was implemented). The control mean reported is for the $2013 / 14$ year. The increase in probability of applying from exposure to the program is estimated from a probit model of the outcome variable regressed on a treatment dummy, along with fixed effects for cohort year and school. Marginal effects at mean values are reported. Standard errors are clustered by school and shown in square brackets. ${ }^{*}, * *$, and $* * *$ indicate statistical significance at the 10,5 , and 1 percent levels respectively. 
Table 7

Phase II Program Effects on Postsecondary Enrollment Rates for Grade 12 Graduates

\begin{tabular}{|c|c|c|c|c|}
\hline Program Design & $\begin{array}{c}\text { Full Sample } \\
\text { (control mean }=0.488 \text { ) }\end{array}$ & $\begin{array}{c}\text { No G12 } \\
\text { Univ. Track Courses } \\
\text { (control mean = 0.297) }\end{array}$ & $\begin{array}{c}\text { Took At Least } 1 \\
\text { G12 Univ. Course } \\
\text { (control mean }=0.602 \text { ) }\end{array}$ & $\begin{array}{c}\text { Took At Least } 1 \\
\text { Vocational Course } \\
\text { (control mean }=0.130 \text { ) }\end{array}$ \\
\hline Baseline & $\begin{array}{l}-0.036 \\
{[0.025]}\end{array}$ & $\begin{array}{c}-0.01 \\
{[0.029]}\end{array}$ & $\begin{array}{l}-0.032 \\
{[0.032]}\end{array}$ & $\begin{array}{c}0.017 \\
{[0.039]}\end{array}$ \\
\hline $\begin{array}{l}\text { Baseline + } \\
\text { "Mop-up" }\end{array}$ & $\begin{array}{c}0 \\
{[0.030]}\end{array}$ & $\begin{array}{l}-0.026 \\
{[0.028]}\end{array}$ & $\begin{array}{c}0.013 \\
{[0.031]}\end{array}$ & $\begin{array}{c}0.045 \\
{[0.068]}\end{array}$ \\
\hline $\begin{array}{l}\text { Internal Staff + } \\
\text { Fee waivers }\end{array}$ & $\begin{array}{c}0.031 \\
{[0.037]}\end{array}$ & $\begin{array}{c}0.081 \\
{[0.035]^{* *}}\end{array}$ & $\begin{array}{c}0.02 \\
{[0.047]}\end{array}$ & $\begin{array}{c}0.01 \\
{[0.034]}\end{array}$ \\
\hline $\begin{array}{l}\text { Baseline with } \\
\text { No fee waiver }\end{array}$ & $\begin{array}{l}-0.027 \\
{[0.042]}\end{array}$ & $\begin{array}{c}-0.085 \\
{[0.051]^{*}}\end{array}$ & $\begin{array}{l}-0.015 \\
{[0.016]}\end{array}$ & $\begin{array}{c}0.02 \\
{[0.074]}\end{array}$ \\
\hline $\begin{array}{l}\text { Internal Staff with } \\
\text { No fee waiver }\end{array}$ & $\begin{array}{l}-0.042 \\
{[0.026]}\end{array}$ & $\begin{array}{c}-0.04 \\
{[0.039]}\end{array}$ & $\begin{array}{l}-0.034 \\
{[0.030]}\end{array}$ & $\begin{array}{c}-0.057 \\
{[0.030]^{*}}\end{array}$ \\
\hline $\begin{array}{l}\text { All schools with } \\
\text { Fee waivers }\end{array}$ & $\begin{array}{l}-0.015 \\
{[0.021]}\end{array}$ & $\begin{array}{l}-0.007 \\
{[0.022]}\end{array}$ & $\begin{array}{l}-0.008 \\
{[0.025]}\end{array}$ & $\begin{array}{c}0.023 \\
{[0.036]}\end{array}$ \\
\hline $\begin{array}{l}\text { All schools with } \\
\text { No fee waiver }\end{array}$ & $\begin{array}{c}-0.038 \\
{[0.023]^{*}}\end{array}$ & $\begin{array}{l}-0.054 \\
{[0.033]}\end{array}$ & $\begin{array}{c}-0.03 \\
{[0.025]}\end{array}$ & $\begin{array}{l}-0.032 \\
{[0.034]}\end{array}$ \\
\hline $\begin{array}{l}\text { Sample Size for All } \\
\text { Schools with Fee }\end{array}$ & 26,330 & 10,598 & 15,732 & 1,721 \\
\hline
\end{tabular}

Notes: Data are from Ontario Ministry of Education student records. The sample includes students with at least 4 years of high school at program and control schools in 2009/10, 2010/11 and 2013/14 (the year Phase II was implemented). The control mean reported is for the 2013/14 year. The increase in probability of enrolling from exposure to the program is estimated from a probit model of the outcome variable regressed on a treatment dummy, along with fixed effects for cohort year and school. Marginal effects at mean values are reported. Standard errors are clustered by school and shown in square brackets. ${ }^{*}, * *$, and $* * *$ indicate statistical significance at the 10,5, and 1 percent respectively. 
Table 8

Phase I and Phase II Effects on Applications and Enrollment

Same Sample of Schools (with fee waivers), Same Time Frame

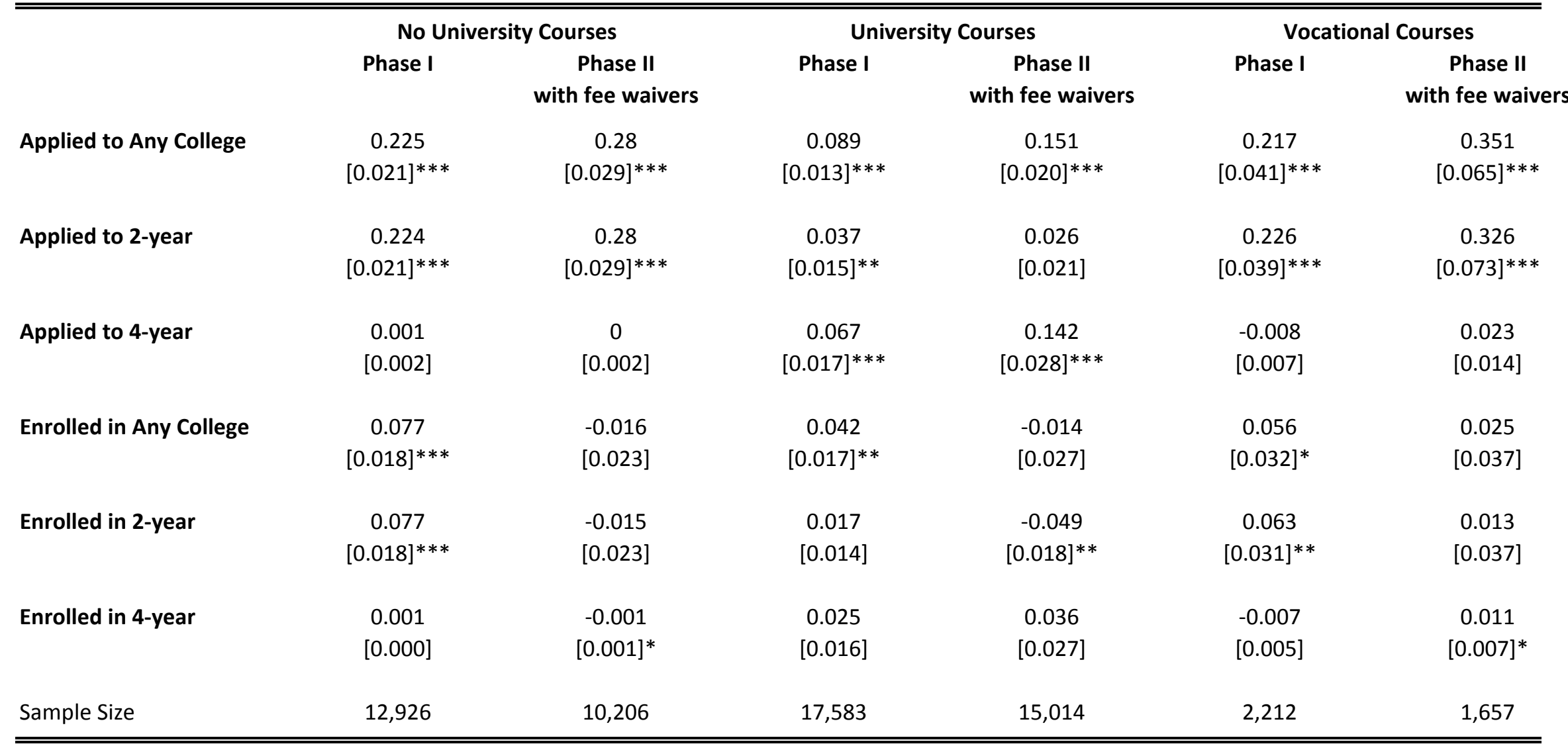

Notes: Data are from Ontario Ministry of Education student records. The sample includes students with at least 4 years of high school at program and control schools in 2009/10, 2010/11 and 2011/12 for Phase I (with the program introduced in 2011/12) and 2009/10, 2010/11 and 2013/14 for Phase II (when the program was introduced in 2013/14). Columns 1-2 show results for students that had not taken any university track courses, columns 3-4 show the opposite. Columns 5-6 show results for students taking at least some workplace/vocational courses. The increase in probability of applying or enrolling from exposure to the program is estimated from a probit model of the outcome variable regressed on a treatment dummy, along with fixed effects for cohort year and school. Marginal effects at mean values are reported. Standard errors are clustered by school and shown in square brackets. *, $* *$, and ${ }^{* * *}$ indicate statistical significance at the 10,5 , and 1 percent levels respectively. 
Table 9

Phase I and Phase II Effects on 2-year Applications and Enrollment Counts

Same Sample of Schools (with fee waivers), Same Time Frame

2-year College Application Data

\begin{tabular}{|c|c|c|}
\hline Panel A & Phase I & $\begin{array}{c}\text { Phase II } \\
\text { with fee waivers }\end{array}$ \\
\hline Applied to & 35.29 & 33.332 \\
\hline 2-year College & {$[6.175]^{* * *}$} & {$[10.675]^{* * *}$} \\
\hline Applied and & 36.321 & 22.07 \\
\hline received offer & {$[6.165]^{* * *}$} & {$[10.546]^{* *}$} \\
\hline Applied and & 1.031 & 11.262 \\
\hline received no offer & [3.644] & {$[5.736]^{*}$} \\
\hline Applied and & 14.664 & -3.738 \\
\hline Accepted & {$[4.557]^{* * *}$} & [6.895] \\
\hline \multicolumn{3}{|l|}{ Panel B } \\
\hline Fraction & 0.091 & 0.138 \\
\hline Applied & {$[0.015]^{* * *}$} & {$[0.028]^{* * *}$} \\
\hline Frac. Applied and & 0.09 & 0.105 \\
\hline received offer & {$[0.012]^{* * *}$} & {$[0.026]^{* * *}$} \\
\hline Frac. Applied and & 0.001 & 0.033 \\
\hline received no offer & [0.008] & {$[0.014]^{* *}$} \\
\hline Frac. Applied and & 0.034 & 0.008 \\
\hline Accpeted & {$[0.009]^{* * *}$} & [0.017] \\
\hline School Sample Size & 172 & 100 \\
\hline
\end{tabular}

Notes: Data are from the Ontario College Application Centre, at the school level. In Panel $A$, the outcome variable is regressed on a treatment dummy, along with cohort and program school fixed effects, weighted by Grade 12 school size. For Phase I schools the cohorts are 2009/10, 2010/11, and 2011/12 (the year of treatment). For Phase II schools the cohort years are 2009/10, 2010/11, and 2013/14 (the year treated). In Panel B the outcome variable is divided by the fraction of Grade 12 Graduates in that school, calcuated from Ministry of Education data. Standard errors are in square brackets, clustered by school. *,**, and *** indicate statistical significance at the 10, 5, and 1 percent levels respectively. 
Appendix Table A1

Estimated Program Effect on All Grade 12 Students by Subgroup

\begin{tabular}{|c|c|c|c|c|c|}
\hline & \multicolumn{2}{|c|}{$\begin{array}{c}\text { Applied to Postsecondary } \\
\text { Program }\end{array}$} & \multicolumn{2}{|c|}{$\begin{array}{c}\text { Enrolled in Postsecondary } \\
\text { Program }\end{array}$} & \multirow[t]{2}{*}{$\begin{array}{l}\text { Sample } \\
\text { Size }\end{array}$} \\
\hline & $\begin{array}{l}\text { Control } \\
\text { Mean }\end{array}$ & $\begin{array}{l}\text { Program } \\
\text { Difference }\end{array}$ & $\begin{array}{l}\text { Control } \\
\text { Mean }\end{array}$ & $\begin{array}{c}\text { Program } \\
\text { Difference }\end{array}$ & \\
\hline Males & 0.323 & $\begin{array}{c}0.139 \\
{[0.016]^{* * *}}\end{array}$ & 0.239 & $\begin{array}{c}0.026 \\
{[0.010]^{* * *}}\end{array}$ & 33,699 \\
\hline Females & 0.481 & $\begin{array}{c}0.133 \\
{[0.016]^{* * *}}\end{array}$ & 0.376 & $\begin{array}{c}0.03 \\
{[0.013]^{* *}}\end{array}$ & 40,107 \\
\hline Urban Schools & 0.382 & $\begin{array}{c}0.136 \\
{[0.014]^{* * *}}\end{array}$ & 0.29 & $\begin{array}{c}0.028 \\
{[0.008]^{* * *}}\end{array}$ & 65,540 \\
\hline Rural Schools & 0.441 & $\begin{array}{c}0.147 \\
{[0.017]^{* * *}}\end{array}$ & 0.343 & $\begin{array}{l}-0.003 \\
{[0.014]}\end{array}$ & 9,490 \\
\hline $\begin{array}{l}\text { Taking At Least One Gr12 } \\
\text { University Track Course }\end{array}$ & 0.623 & $\begin{array}{c}0.157 \\
{[0.016]^{* * *}}\end{array}$ & 0.483 & $\begin{array}{c}0.034 \\
{[0.014]^{* *}}\end{array}$ & 33,699 \\
\hline $\begin{array}{l}\text { Taking No Grade } 12 \\
\text { University Track Course }\end{array}$ & 0.194 & $\begin{array}{c}0.139 \\
{[0.014]^{* * *}}\end{array}$ & 0.141 & $\begin{array}{c}0.038 \\
{[0.007]^{* * *}}\end{array}$ & 41,331 \\
\hline $\begin{array}{l}\text { Taking Gr12 Vocational } \\
\text { Math or English }\end{array}$ & 0.102 & $\begin{array}{c}0.185 \\
{[0.044]^{* * *}}\end{array}$ & 0.051 & $\begin{array}{c}0.032 \\
{[0.019]^{*}}\end{array}$ & 4,061 \\
\hline $\begin{array}{l}\text { Taking No Grade } 12 \\
\text { Vocational Math or English }\end{array}$ & 0.4116 & $\begin{array}{c}0.138 \\
{[0.013]^{* * *}}\end{array}$ & 0.3001 & $\begin{array}{c}0.03 \\
{[0.008]^{* * *}}\end{array}$ & 70,969 \\
\hline Grade Average $<60 \%$ & 0.137 & $\begin{array}{c}0.074 \\
{[0.014]^{* * *}}\end{array}$ & 0.083 & $\begin{array}{c}0.015 \\
{[0.007]^{* *}}\end{array}$ & 22,528 \\
\hline Grade Average Btw. 60-75\% & 0.419 & $\begin{array}{c}0.183 \\
{[0.019]^{* * *}}\end{array}$ & 0.309 & $\begin{array}{c}0.047 \\
{[0.011]^{* * *}}\end{array}$ & 28,319 \\
\hline Grade Average $>=75 \%$ & 0.575 & $\begin{array}{c}0.175 \\
{[0.016]^{* * *}}\end{array}$ & 0.467 & $\begin{array}{c}0.046 \\
{[0.017]^{* * *}}\end{array}$ & 24,183 \\
\hline
\end{tabular}

Notes: Same as in Table 4. The only difference in setup for this table compared to Table 5 is the sample population of all students with at least 4 years of high school, instead of the subset of all existing students with a high school degree. 
Appendix Table A2

Estimated Program Effect on Grade 12 Students Beginning with At Least 21 Credits by Subgroup

\begin{tabular}{|c|c|c|c|c|c|}
\hline & \multicolumn{2}{|c|}{$\begin{array}{c}\text { Applied to Postsecondary } \\
\text { Program }\end{array}$} & \multicolumn{2}{|c|}{$\begin{array}{c}\text { Enrolled in Postsecondary } \\
\text { Program }\end{array}$} & \multirow[t]{2}{*}{$\begin{array}{l}\text { Sample } \\
\text { Size }\end{array}$} \\
\hline & $\begin{array}{l}\text { Control } \\
\text { Mean }\end{array}$ & $\begin{array}{l}\text { Program } \\
\text { Difference }\end{array}$ & $\begin{array}{l}\text { Control } \\
\text { Mean }\end{array}$ & $\begin{array}{c}\text { Program } \\
\text { Difference }\end{array}$ & \\
\hline Males & 0.476 & $\begin{array}{c}0.2 \\
{[0.022]^{* * *}}\end{array}$ & 0.367 & $\begin{array}{c}0.042 \\
{[0.017]^{* *}}\end{array}$ & 21132 \\
\hline Females & 0.652 & $\begin{array}{c}0.178 \\
{[0.016]^{* * *}}\end{array}$ & 0.525 & $\begin{array}{c}0.044 \\
{[0.018]^{* *}}\end{array}$ & 20513 \\
\hline Urban Schools & 0.559 & $\begin{array}{c}0.187 \\
{[0.017]^{* * *}}\end{array}$ & 0.44 & $\begin{array}{c}0.04 \\
{[0.014]^{* * *}}\end{array}$ & 35407 \\
\hline Rural Schools & 0.567 & $\begin{array}{c}0.208 \\
{[0.013]^{* * *}}\end{array}$ & 0.452 & $\begin{array}{c}0.047 \\
{[0.023]^{* *}}\end{array}$ & 6,238 \\
\hline $\begin{array}{l}\text { Taking At Least One Gr12 } \\
\text { University Track Course }\end{array}$ & 0.371 & $\begin{array}{c}0.165 \\
{[0.016]^{* * *}}\end{array}$ & 0.535 & $\begin{array}{c}0.031 \\
{[0.015]^{* *}}\end{array}$ & 27,344 \\
\hline $\begin{array}{l}\text { Taking No Gr12 } \\
\text { University Track Course }\end{array}$ & 0.362 & $\begin{array}{c}0.26 \\
{[0.022]^{* * *}}\end{array}$ & 0.279 & $\begin{array}{c}0.084 \\
{[0.016]^{* * *}}\end{array}$ & 15,375 \\
\hline $\begin{array}{l}\text { Taking Gr12 Vocational } \\
\text { Math or English }\end{array}$ & 0.12 & $\begin{array}{c}0.339 \\
{[0.090]^{* * *}}\end{array}$ & 0.082 & $\begin{array}{c}0.062 \\
{[0.044]}\end{array}$ & 1,624 \\
\hline $\begin{array}{l}\text { Taking No Gr12 } \\
\text { Vocational Math or English }\end{array}$ & 0.581 & $\begin{array}{c}0.186 \\
{[0.015]^{* * *}}\end{array}$ & 0.46 & $\begin{array}{c}0.043 \\
{[0.013]^{* * *}}\end{array}$ & 41,095 \\
\hline Grade Average $<60 \%$ & 0.27 & $\begin{array}{c}0.225 \\
{[0.046]^{* * *}}\end{array}$ & 0.183 & $\begin{array}{c}0.051 \\
{[0.032]}\end{array}$ & 3,951 \\
\hline Grade Average Btw. 60-75\% & 0.49 & $\begin{array}{c}0.206 \\
{[0.021]^{* * *}}\end{array}$ & 0.372 & $\begin{array}{c}0.051 \\
{[0.015]^{* * *}}\end{array}$ & 20,205 \\
\hline Grade Average $>=75 \%$ & 0.692 & $\begin{array}{c}0.173 \\
{[0.015]^{* * *}}\end{array}$ & 0.569 & $\begin{array}{c}0.043 \\
{[0.018]^{* *}}\end{array}$ & 18,563 \\
\hline
\end{tabular}

Notes: Same as in Table 4. The only difference in setup for this table compared to Table 5 is the sample population of all students with at least 4 years of high school starting the year with at least 21 credits, instead of the subset of all existing students with a high school degree. 
Appendix Table A3

Estimated Program Effects on Grade 12 Graduates with Added Individual Control Variables

\begin{tabular}{|c|c|c|c|c|c|}
\hline \multirow[b]{3}{*}{ Full Sample } & \multicolumn{2}{|c|}{$\begin{array}{c}\text { Applied to Postsecondary } \\
\text { Program }\end{array}$} & \multicolumn{2}{|c|}{$\begin{array}{c}\text { Enrolled in Postsecondary } \\
\text { Program }\end{array}$} & \multirow[t]{2}{*}{$\begin{array}{l}\text { Sample } \\
\text { Size }\end{array}$} \\
\hline & $\begin{array}{l}\text { Control } \\
\text { Mean }\end{array}$ & $\begin{array}{c}\text { Program } \\
\text { Difference }\end{array}$ & $\begin{array}{l}\text { Control } \\
\text { Mean }\end{array}$ & $\begin{array}{c}\text { Program } \\
\text { Difference }\end{array}$ & \\
\hline & 0.654 & $\begin{array}{c}0.155 \\
{[0.012]^{* * *}}\end{array}$ & 0.549 & $\begin{array}{c}0.063 \\
{[0.012]^{* * *}}\end{array}$ & 38,352 \\
\hline Males & 0.568 & $\begin{array}{c}0.181 \\
{[0.021]^{* * *}}\end{array}$ & 0.463 & $\begin{array}{c}0.073 \\
{[0.016]^{* * *}}\end{array}$ & 18,978 \\
\hline Females & 0.743 & $\begin{array}{c}0.126 \\
{[0.011]^{* * *}}\end{array}$ & 0.624 & $\begin{array}{c}0.051 \\
{[0.016]^{* * *}}\end{array}$ & 19,374 \\
\hline Urban Schools & 0.65 & $\begin{array}{c}0.156 \\
{[0.014]^{* * *}}\end{array}$ & 0.539 & $\begin{array}{c}0.063 \\
{[0.013]^{* * *}}\end{array}$ & 32,832 \\
\hline Rural Schools & 0.668 & $\begin{array}{c}0.159 \\
{[0.021]^{* * *}}\end{array}$ & 0.553 & $\begin{array}{c}0.07 \\
{[0.036]^{*}}\end{array}$ & 5,520 \\
\hline $\begin{array}{l}\text { Taking At Least One Gr12 } \\
\text { University Track Course }\end{array}$ & 0.83 & $\begin{array}{c}0.077 \\
{[0.009]^{* * *}}\end{array}$ & 0.703 & $\begin{array}{c}0.038 \\
{[0.014]^{* * *}}\end{array}$ & 22,226 \\
\hline $\begin{array}{l}\text { Taking No Gr12 } \\
\text { University Track Course }\end{array}$ & 0.409 & $\begin{array}{c}0.242 \\
{[0.021]^{* * *}}\end{array}$ & 0.318 & $\begin{array}{c}0.085 \\
{[0.016]^{* * *}}\end{array}$ & 16,126 \\
\hline $\begin{array}{l}\text { Taking Gr12 Vocational } \\
\text { Math or English }\end{array}$ & 0.167 & $\begin{array}{c}0.377 \\
{[0.068]^{* * *}}\end{array}$ & 0.108 & $\begin{array}{c}0.112 \\
{[0.047]^{* *}}\end{array}$ & 1,753 \\
\hline $\begin{array}{l}\text { Taking No Gr12 } \\
\text { Vocational Math or English }\end{array}$ & 0.681 & $\begin{array}{c}0.144 \\
{[0.012]^{* * *}}\end{array}$ & 0.566 & $\begin{array}{c}0.06 \\
{[0.012]^{* * *}}\end{array}$ & 36,599 \\
\hline Grade Average $<60 \%$ & 0.413 & $\begin{array}{c}0.188 \\
{[0.034]^{* * *}}\end{array}$ & 0.3 & $\begin{array}{c}0.067 \\
{[0.029]^{* *}}\end{array}$ & 5,150 \\
\hline Grade Average Btw. 60-75\% & 0.598 & $\begin{array}{c}0.179 \\
{[0.019]^{* * *}}\end{array}$ & 0.483 & $\begin{array}{c}0.077 \\
{[0.017]^{* * *}}\end{array}$ & 16,777 \\
\hline Grade Average>=75\% & 0.777 & $\begin{array}{c}0.103 \\
{[0.009]^{* * *}}\end{array}$ & 0.668 & $\begin{array}{c}0.041 \\
{[0.016]^{* *}}\end{array}$ & 16,425 \\
\hline
\end{tabular}

Notes: Same as in Table 4. The only difference in setup for this table compared to Table 5 is that the regression also includes the following conditional variables: : a dummy for having taken university-track courses in high school interacted with high school grade average, number of credits earned at the start of a student's last year of high school, total number of courses failed in high school, age fixed effects, and dummy variables for gender, for taking university-track or workplace-track courses in grade 11, for whether the student was ever in special education classes, for being an immigrant, and for whether their mother tongue is neither French nor English. 


\section{Appendix Table A4}

Estimated Program Effect Using Program Year Only (2011-12)

All Grade 12 Sample Versus Graduate Only Sample, With and Without Individual Controls

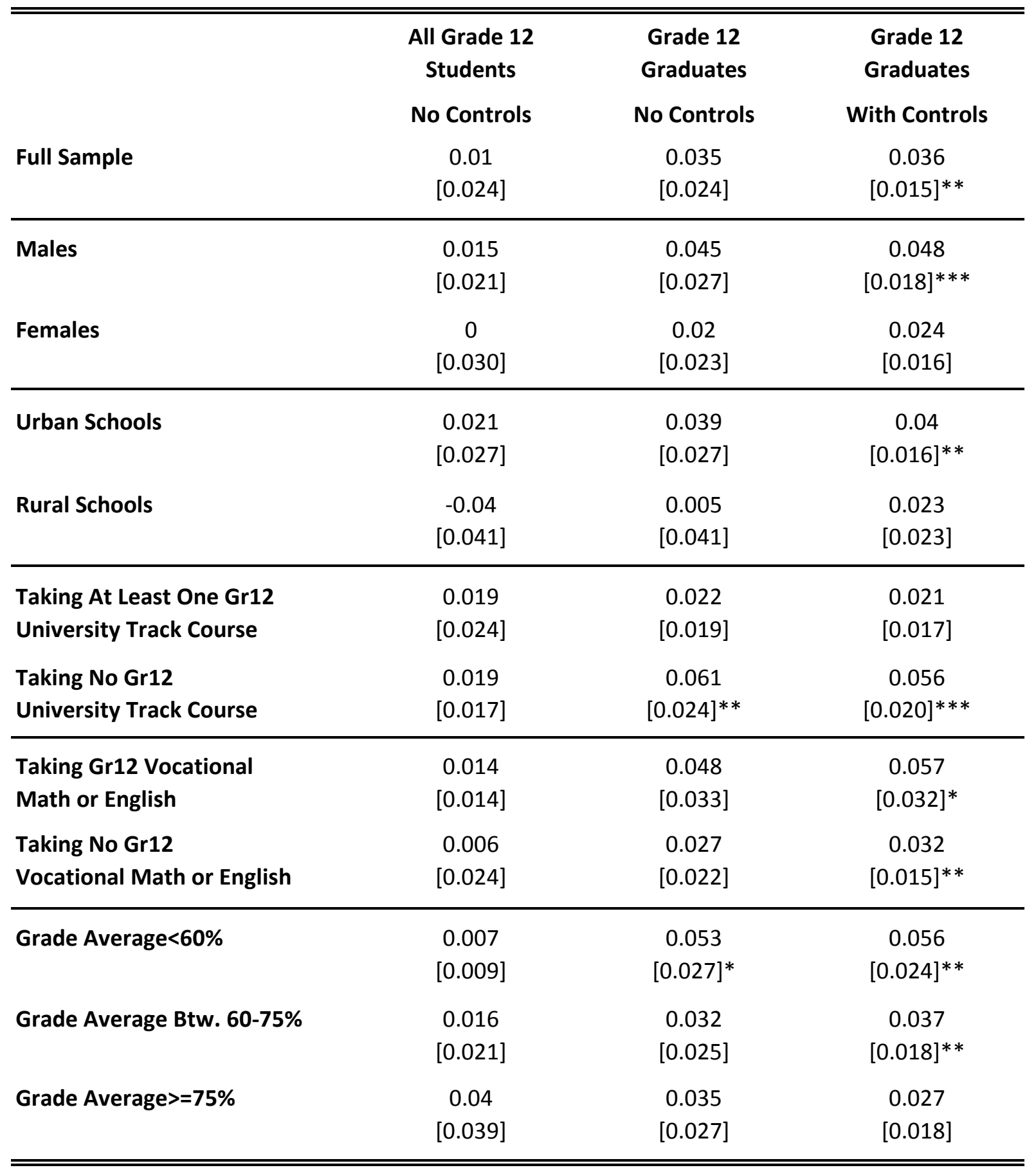

Notes: Estimated effects are simply differences in mean outcomes between progran and control schools in 2011-12, the year the Phase I program was implemented. Standard errors are in square brackets. The additional control variables used in Column 3 are the same as those used in Appendix Table A3. ${ }^{*}, * *$, and $* * *$ indicate statistical significance at the 10,5 , and 1 percent levels respectively. 
Appendix Table A5

Phase II Program Effects on Application Rates for Grade 12 Students Beginning with At Least 21 Credits

\begin{tabular}{|c|c|c|c|c|}
\hline Program Design & $\begin{array}{c}\text { Full Sample } \\
\text { (control mean }=0.603 \text { ) }\end{array}$ & $\begin{array}{c}\text { No Gr12 } \\
\text { Univ. Track Courses } \\
\text { (control mean }=0.371 \text { ) }\end{array}$ & $\begin{array}{c}\text { Took At Least } 1 \\
\text { Gr12 Univ. Course } \\
\text { (control mean }=0.729 \text { ) }\end{array}$ & $\begin{array}{c}\text { Took At Least } 1 \\
\text { Vocational Course } \\
\text { (control mean }=0.209 \text { ) }\end{array}$ \\
\hline Baseline & $\begin{array}{c}0.234 \\
{[0.020]^{* * *}}\end{array}$ & $\begin{array}{c}0.323 \\
{[0.037]^{* * *}}\end{array}$ & $\begin{array}{c}0.199 \\
{[0.028]^{* * *}}\end{array}$ & $\begin{array}{c}0.271 \\
{[0.124]^{* *}}\end{array}$ \\
\hline $\begin{array}{l}\text { Baseline + } \\
\text { "Mop-up" }\end{array}$ & $\begin{array}{c}0.26 \\
{[0.032]^{* * *}}\end{array}$ & $\begin{array}{c}0.351 \\
{[0.054]^{* * *}}\end{array}$ & $\begin{array}{c}0.207 \\
{[0.035]^{* * *}}\end{array}$ & $\begin{array}{c}0.642 \\
{[0.129]^{* * *}}\end{array}$ \\
\hline $\begin{array}{l}\text { Internal Staff + } \\
\text { Fee waivers }\end{array}$ & $\begin{array}{c}0.261 \\
{[0.100]^{* * *}}\end{array}$ & $\begin{array}{c}0.43 \\
{[0.109]^{* * *}}\end{array}$ & $\begin{array}{c}0.177 \\
{[0.096]^{*}}\end{array}$ & $\begin{array}{c}0.218 \\
{[0.321]}\end{array}$ \\
\hline $\begin{array}{l}\text { Baseline with } \\
\text { No fee waiver }\end{array}$ & $\begin{array}{c}0.003 \\
{[0.066]}\end{array}$ & $\begin{array}{l}-0.077 \\
{[0.057]}\end{array}$ & $\begin{array}{c}0.063 \\
{[0.026]^{* *}}\end{array}$ & $\begin{array}{l}-0.026 \\
{[0.053]}\end{array}$ \\
\hline $\begin{array}{l}\text { Internal Staff with } \\
\text { No fee waiver }\end{array}$ & $\begin{array}{l}-0.033 \\
{[0.027]}\end{array}$ & $\begin{array}{c}0.01 \\
{[0.050]}\end{array}$ & $\begin{array}{c}-0.062 \\
{[0.020]^{* * *}}\end{array}$ & $\begin{array}{l}-0.035 \\
{[0.052]}\end{array}$ \\
\hline $\begin{array}{l}\text { All schools with } \\
\text { Fee waivers }\end{array}$ & $\begin{array}{c}0.247 \\
{[0.023]^{* * *}}\end{array}$ & $\begin{array}{c}0.341 \\
{[0.033]^{* * *}}\end{array}$ & $\begin{array}{c}0.199 \\
{[0.025]^{* * *}}\end{array}$ & $\begin{array}{c}0.343 \\
{[0.113]^{* * *}}\end{array}$ \\
\hline $\begin{array}{l}\text { All schools with } \\
\text { No fee waiver }\end{array}$ & $\begin{array}{l}-0.025 \\
{[0.028]}\end{array}$ & $\begin{array}{l}-0.012 \\
{[0.043]}\end{array}$ & $\begin{array}{l}-0.036 \\
{[0.025]}\end{array}$ & $\begin{array}{l}-0.034 \\
{[0.046]}\end{array}$ \\
\hline $\begin{array}{l}\text { Sample Size for All } \\
\text { Schools with Fee }\end{array}$ & aivers & 9,456 & 17,534 & 1,257 \\
\hline
\end{tabular}

Notes: Data are from Ontario Ministry of Education student records. The sample includes students with at least 4 years of high school with at least 21 credits at the start of the cohort year at program and control schools in 2009/10, 2010/11 and 2013/14 (the year Phase II was implemented). The control mean reported is for the $2013 / 14$ year. The increase in probability of applying from exposure to the program is estimated from a probit model of the outcome variable regressed on a treatment dummy, along with fixed effects for cohort year and school. Marginal effects at mean values are reported. Standard errors are clustered by school and shown in square brackets. $*, * *$, and $* * *$ indicate statistical significance at the 10,5 , and 1 percent levels respectively. 
Appendix Table A6

Phase II Program Effects on Enrollment Rates for Grade 12 Graduates Beginning with At Least 21 Credits

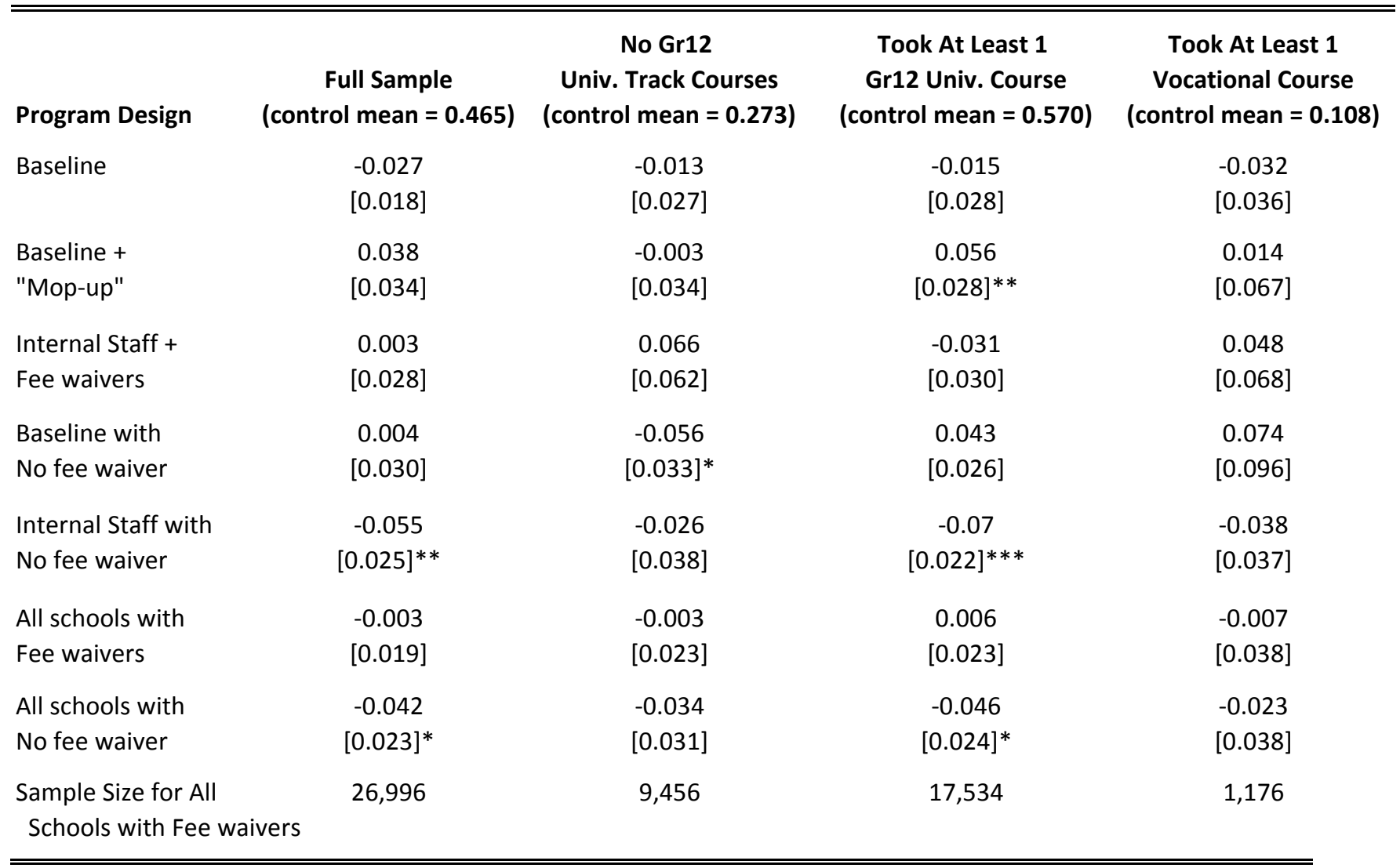

Notes: Data are from Ontario Ministry of Education student records. The sample includes students with at least 4 years of high school at 21 credits at the start of the cohort year at program and control schools in 2009/10, 2010/11 and 2013/14 (the year Phase II was implemented). The control mean reported is for the 2013/14 year. The increase in probability of enrolling from exposure to the program is estimated from a probit model of the outcome variable regressed on a treatment dummy, along with fixed effects for cohort year and school. Marginal effects at mean values are reported. Standard errors are clustered by school and shown in square brackets. $*, * *$, and $* * *$ indicate statistical significance at the 10, 5, and 1 percent levels respectively. 
Figure 2A

Control and Program School Postsecondary Application Rates for Grade 12 Graduates 2009-10 to 2012-13

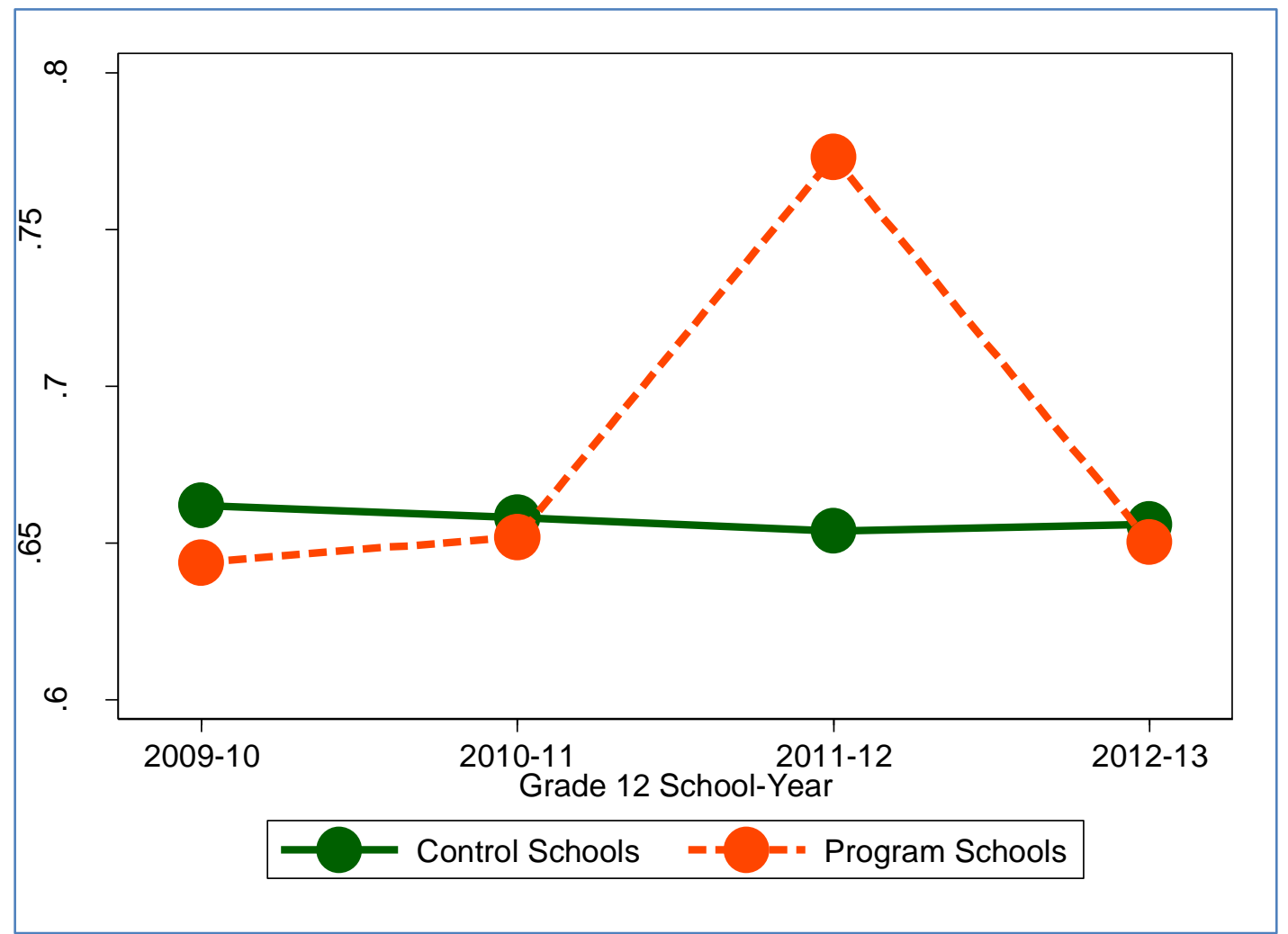

Notes: The fraction of Grade 12 graduates applying to any postsecondary institution is calculated for each control and program school. The values in the figure show the average application rates for control and treated schools, weighted by the sample size in each school. 
Figure 2B

Control and Program School Postsecondary Enrollment Rates for Grade 12 Graduates 2009-10 to 2012-13

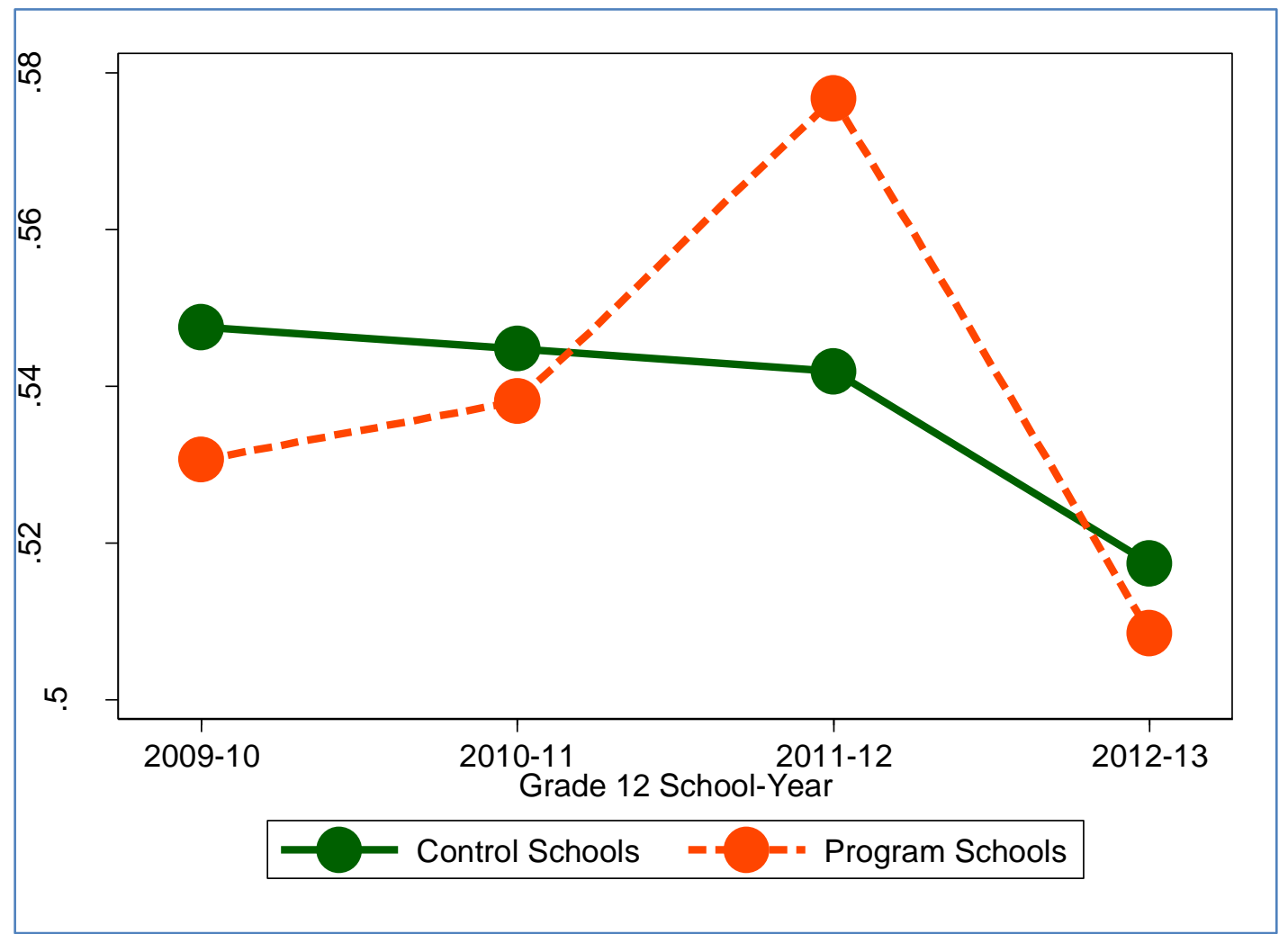

Notes: The fraction of Grade 12 graduates enrolling in any postsecondary institution is calculated for each control and program school. The values in the figure show the average enrollment rates for control and treated schools, weighted by the sample size in each school. 